\title{
CORRECTIVE ACTION PLAN FOR CORRECTIVE ACTION UNIT 453: AREA 9 UXO LANDFLL TONOPAH TEST RANGE, NEVADA
}

\author{
Prepared for \\ U. S. Department of Energy \\ Nevada Operations Office \\ Under Contract No. DE-AC08-96NV11718 \\ Revision: 0 \\ Prepared by \\ Bechtel Nevada \\ Environmental Restoration
}

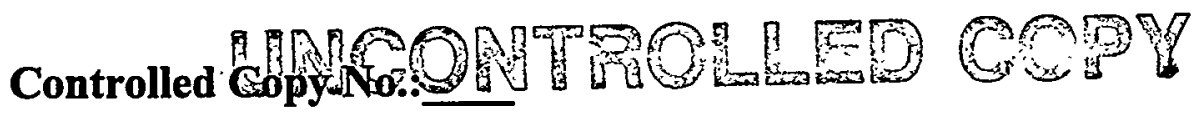

September 1998 


\section{DISCLAIMER}

This report was prepared as an account of work sponsored by an agency of the United States Government. Neither the United States Government nor any agency thereof, nor any of their employees, make any warranty, express or implied, or assumes any legal liability or responsibility for the accuracy, completeness, or usefulness of any information, apparatus, product, or process disclosed, or represents that its use would not infringe privately owned rights. Reference herein to any specific commercial product, process, or service by trade name, trademark, manufacturer, or otherwise does not necessarily constitute or imply its endorsement, recommendation, or favoring by the United States Government or any agency thereof. The views and opinions of authors expressed herein do not necessarily state or reflect those of the United States Government or any agency thereof. 


\section{DISCLAIMER}

Portions of this document may be illegible in electronic image products. Images are produced from the best available original document. 


\section{CORRECTIVE ACTION PLAN FOR CORRECTIVE ACTION UNIT 453: AREA 9 UXO LANDFILL TONOPAH TEST RANGE, NEVADA}

Approved by: Industrial Sites Subproject
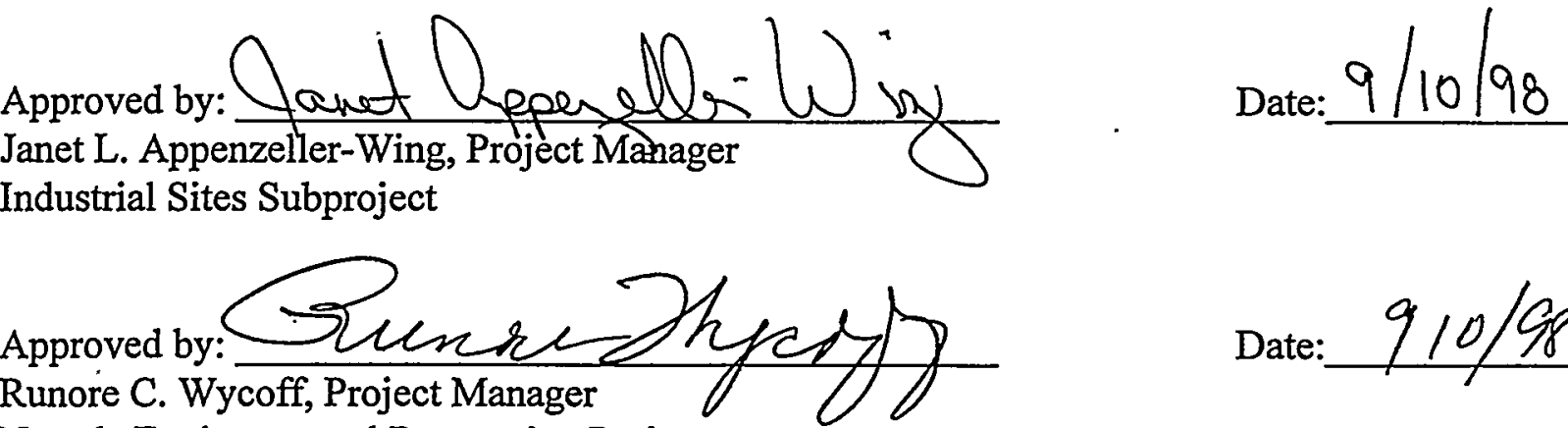

Date: $910 / 98$ Nevada Environmental Restoration Project' 


\section{TABLE OF CONTENTS}

FIGURES $\ldots \ldots \ldots \ldots \ldots \ldots \ldots \ldots \ldots \ldots \ldots \ldots \ldots \ldots \ldots \ldots \ldots \ldots \ldots$ iv

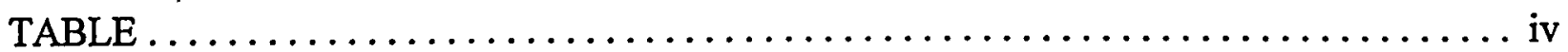

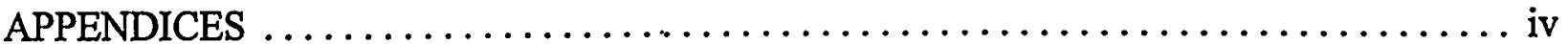

ACRONYMS AND ABBREVIATIONS $\ldots \ldots \ldots \ldots \ldots \ldots \ldots \ldots \ldots \ldots \ldots \ldots \ldots \ldots$

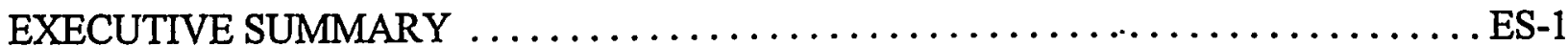

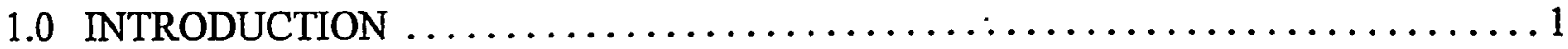

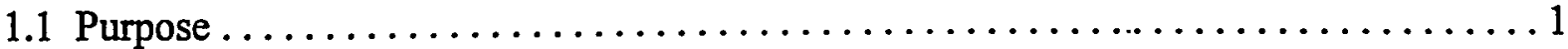

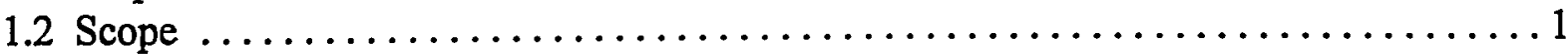

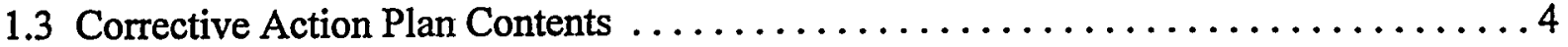

2.0 DETAILED STATEMENT OF WORK $\ldots \ldots \ldots \ldots \ldots \ldots \ldots \ldots \ldots \ldots \ldots \ldots \ldots \ldots \ldots \ldots \ldots \ldots$

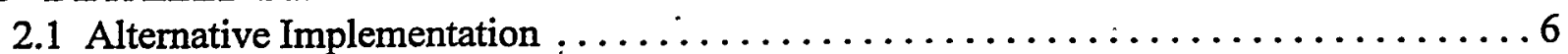

2.1.1 Backfilling and Grading the Open Portion of Cell A9-1 $\ldots \ldots \ldots \ldots \ldots \ldots$

2.1.2 Installation of Fencing, Warning Signs, and Monuments ............. 9

2.1.3 Implementation of Administrative Controls to Restrict Land Use . . . . . . . 10

2.2 Construction Quality Assurance / Quality Control $\ldots \ldots \ldots \ldots \ldots \ldots \ldots \ldots \ldots$

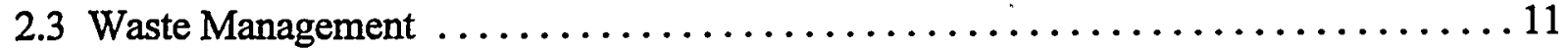

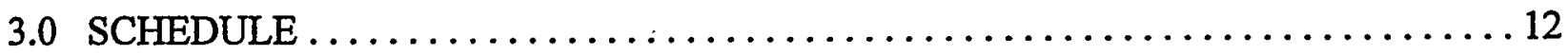

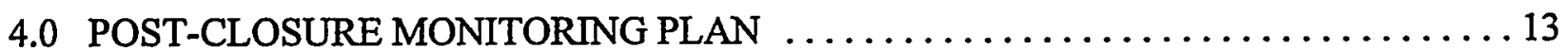

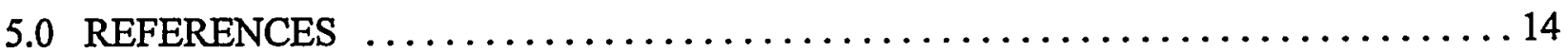




\section{TABLE OF CONTENTS (continued)}

\section{FIGURES}

FIGURE 1 - LOCATION OF THE AREA 9 UXO LANDFILL

AT THE TONOPAH TEST RANGE $\ldots \ldots \ldots \ldots \ldots \ldots \ldots \ldots \ldots \ldots \ldots \ldots \ldots \ldots \ldots$

FIGURE 2 - SITE PLAN FOR THE AREA 9 UXO LANDFILL $\ldots \ldots \ldots \ldots \ldots \ldots$

\section{TABLE}

TABLE 1 - SUMMARY OF GEOTECHNICAL TEST RESULTS $\ldots \ldots \ldots \ldots \ldots \ldots \ldots 7$

\section{APPENDICES}

APPENDIX A - ENGINEERING DRAWINGS

APPENDIX B - GEOTECHNICAL TEST RESULTS 


\section{ACRONYMS AND ABBREVIATIONS}

ASTM - American Society for Testing and Materials

CADD Corrective Action Decision Document

CAIP Corrective Action Investigation Plan

CAP Corrective Action Plan

CAS Corrective Action Site

CAU Corrective Action Unit

cm centimeters

DOE U.S. Department of Energy

EPA U. S. Environmental Protection Agency

$\mathrm{ft} \quad$ feet

$\mathrm{ft}^{3} \quad$ cubic feet

in inches

$\mathrm{km} \quad$ kilometers

lbs pounds

m meters

$\mathrm{m}^{3} \quad$ cubic meters

mi miles

NDEP Nevada Division of Environmental Protection

PRG Preliminary Remediation Goal 


\section{ACRONYMS AND ABBREVIATIONS (continued)}

RCRA Resource Conservation and Recovery Act

sec second

TTR Tonopah Test Range

UXO unexploded ordnance

$\mathrm{yd}^{3} \quad$ cubic yards 


\section{EXECUTIVE SUMMARY}

This Corrective Action Plan (CAP) proposes the closure methods for the Area 9 Unexploded Ordnance (UXO) Landfill, Corrective Action Unit (CAU) 453, located at the Tonopah Test Range (TTR). The Area 9 UXO Landfill CAU consists of Corrective Action Site (CAS) No. 09-55-001-0952 and is comprised of three individual landfill cells designated as A9-1, A9-2, and A9-3.

The three landfill cells received wastes from daily operations at Area 9 and from range cleanups which were performed after weapons testing. Cell locations and contents were not well documented due to the unregulated disposal practices commonly associated with early landfill operations. However, site process knowledge indicates that the landfill cells were used for solid waste disposal, including disposal of UXO.

A corrective action investigation was performed in 1997 and results were reported in the Corrective Action Décision Document (CADD) (DOE, 1998). Although cell contents were not investigated directly due to the potential for live UXO, undisturbed soils beneath the cells were sampled using angled borings. The CADD reported that no hazardous waste was found in the corrective action investigation. The Environmental Protection Agency (EPA) Preliminary Remediation Goal (PRG) for arsenic was exceeded in approximately half of the soil samples collected from beneath the landfill cells and in five of six background soil samples. In addition, the highest arsenic concentration was measured in a background sample. The corrective action objective is to prevent inadvertent contact with landfill debris and live UXO, and will be accomplished with the following closure activities:

- Backfill and grade the open portion of Cell A9-1 to minimize surface depressions.

- Erect signs to warn of buried wastes, monuments to denote cell locations, and a perimeter fence to restrict access.

- $\quad$ Enact use restrictions to control access and prevent intrusive activities. 


\subsection{INTRODUCTION}

This Corrective Action Plan (CAP) describes the selected corrective action alternative and proposes the closure methods for the Area 9 Unexploded Ordnance (UXO) Landfill Corrective Action Unit (CAU) No. 453 at the Tonopah Test Range (TTR). The TTR is located approximately 225 kilometers $(\mathrm{km})$ (140 miles [mi]) northwest of Las Vegas, Nevada (Figure 1).

The Area 9 UXO Landfill CAU consists of a single Corrective Action Site (CAS) No. 09-55001-0952, which is comprised of three northeast-southwest trending landfill cells designated as Cells A9-1, A9-2, and A9-3 (Figure 2). The landfill cells were operated during different time intervals beginning in the early 1960 s through 1993, and received waste generated from daily operations at Area 9 and from range cleanups which occurred after weapons testing. Cell contents were not well documented during early landfill operations, but site process knowledge indicates they were used for solid waste disposal, including disposal of UXO. The landfill cells are backfilled to grade except for a depression in the northeast end of Cell A9-1 where all debris was removed during a voluntary cleanup performed in 1995 and described in the Corrective Action Investigation Plan (CAIP) (Department of Energy [DOE], 1997).

The CAIP (DOE, 1997) described how cell locations were identified from worker interviews, TTR reports, historical aerial photographs, and geophysical surveys. The Corrective Action Decision Document (CADD) (DOE, 1998) described the 1997 field investigation to characterize the landfill cells. Buried contents of the landfill cells were not investigated in the 1997. corrective action investigation due to the potential for live UXO. Instead, undisturbed soil from beneath the landfill cells was sampled using angled borings. Although no landfill wastes were found in excess of regulatory action levels or background concentrations, the CADD (DOE, 1998) concluded that corrective actions were needed to prevent inadvertent contact with landfill debris and potential live UXO.

\subsection{PURPOSE}

The purpose of this CAP is to provide the methods for undertaking the corrective action alternative as provided in the CADD (DOE, 1998).

\subsection{SCOPE}

The scope of this plan is to provide the methods for implementation of the closure of CAU 453. Corrective action Alternative 2 was selected in the CADD (DOE, 1998) and includes a number 


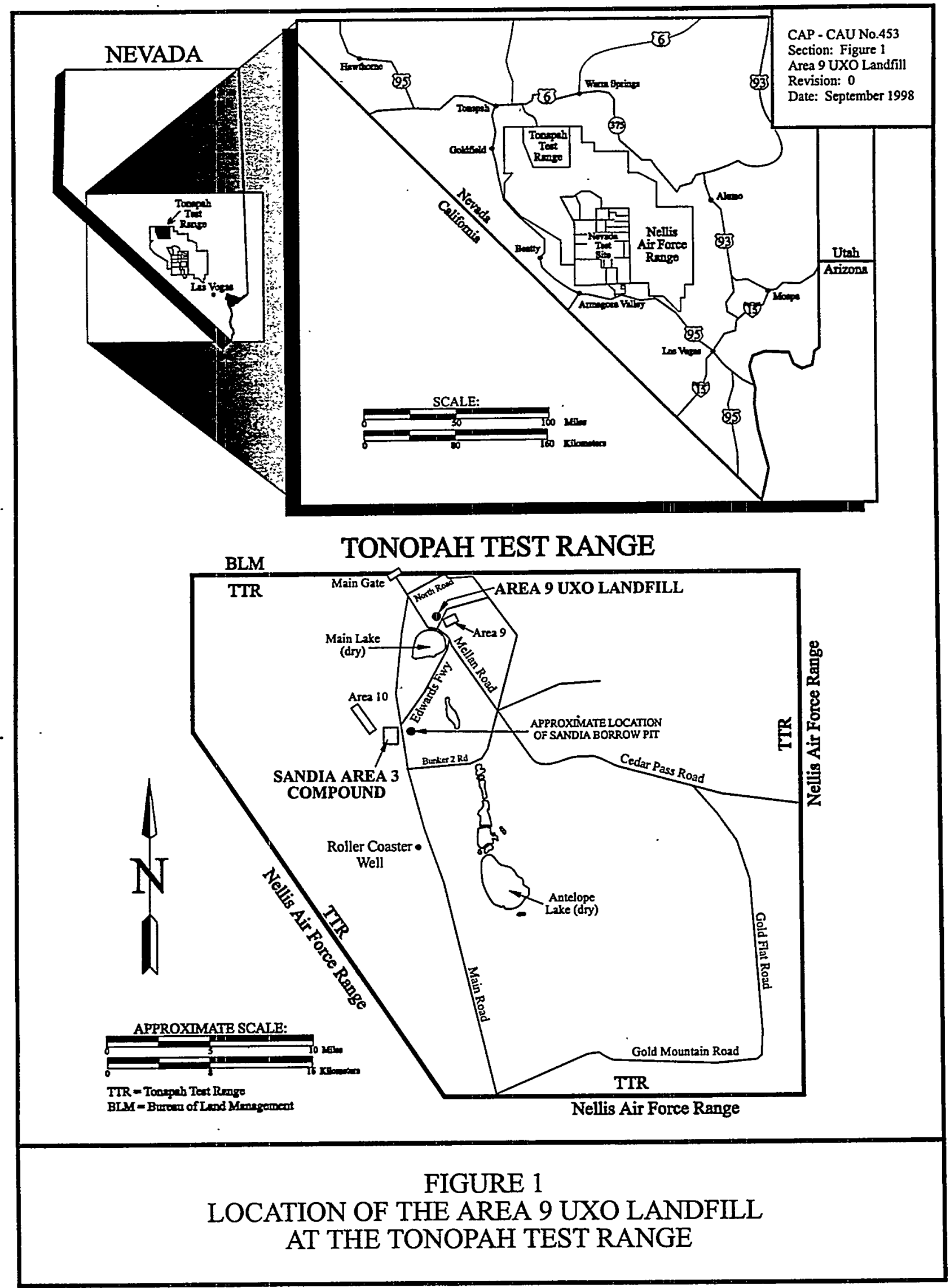




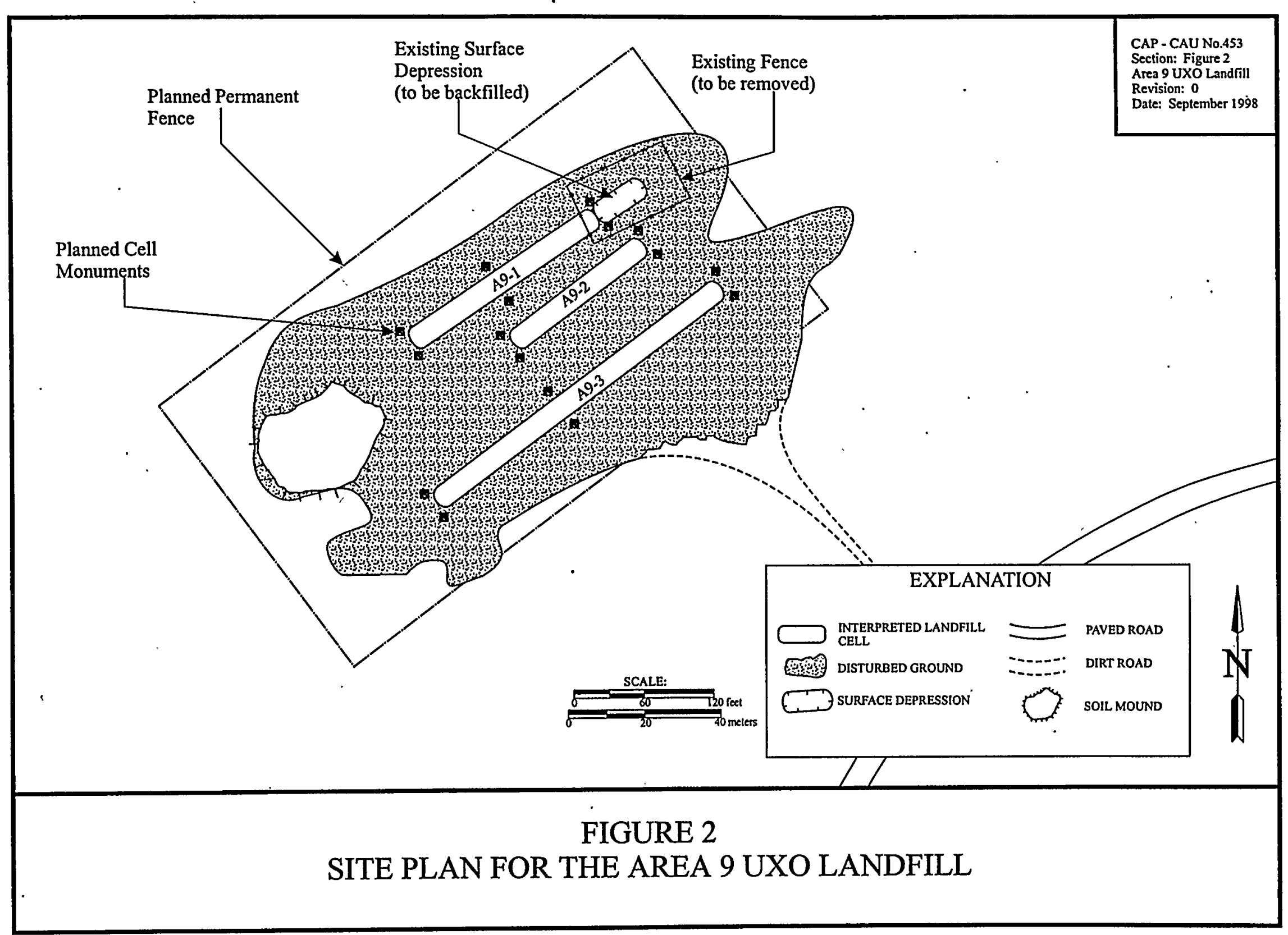


of steps to prevent inadvertent contact with landfill debris and UXO. Alternative 2 consists of the following closure activities:

- $\quad$ Backfill and grade the open portion of Cell A9-1.

- Install warning signs, cell-corner monuments, and perimeter fencing.

- Enact use restrictions to control access and prevent intrusive activities.

Additionally, the Nevada Division of Environmental Protection (NDEP) requested justification for not installing additional capping material at the existing landfill cells by providing permeability, compaction, and existing cap thickness information (NDEP, 1998). Compaction and permeability testing was conducted in July and August, 1998. The existing cap thicknesses were determined during the 1997 investigation activities. The results are discussed in Section 2.1 .

\subsection{CORRECTIVE ACTION PLAN CONTENTS}

This CAP is divided into the following sections:

- Section 1.0 Introduction.

- Section 2.0 Detailed Statement of Work.

- Section 3.0 Schedule. \&

- Section 4.0 Post-Closure Monitoring Plan.

- Section 5.0 References.

- $\quad$ Appendix A Engineering Drawings.

- $\quad$ Appendix B Geotechnical Test Results.

This plan was developed using information and guidance from the following documents:

- 1997 Annual Book Of ASTM Standards, Volume 04.08, Soil and Rock (I): D 420 - D 4914. 
- $\quad$ Corrective Action Decision Document, Area 9 UXO Landfill, Rev. 0, DOE/NV-497, . DOE, 1998.

- Corrective Action Investigation Plan, Area 9 UXO Landfill, Rev. 0, DOE/NV-475, DOE, 1997.

- $\quad$ NDEP, 1998, July 13, 1998 Letter from Karen K. Beckley to Runore C. Wycoff, RE: Draft CAP for CAU 453: Area 9 UXO Landfill, TTR, June 1998.

- Nevada Environmental Restoration Project. Health and Safety Plan, DOE, 1996.

- Nevada Environmental Restoration Project, Industrial Sites, Quality Assurance Project Plan, Nevada Test Site, Rev. 1, DOE/NV-425, DOE, 1996.

- $\quad$ Region IX Preliminary Remediation Goals (PRGs), EPA, 1996.

- Voluntary Corrective Action Plan For Ordnance Removal From Five Disposal Sites At The Tonopah Test Range, DOE/NV-386 UC-700, DOE, 1995. 


\subsection{DETAILED STATEMENT OF WORK}

\subsection{ALTERNATIVE IMPLEMENTATION}

The objective of the corrective action alternative selected in the CADD (DOE, 1998) is to prevent inadvertent intrusion and contact with the solid waste and potentially live UXO.

On July 13, 1998, the NDEP requested engineering information for the existing landfill cap (permeability, compaction, and thickness) and justification for not conducting additional capping of the landfill cells (NDEP, 1998). Compaction tests (ASTM, 1997a [nuclear density testing]) were conducted at the surface of the existing covers. Soil samples of the existing covers were collected for permeability testing (ASTM, 1997b [constant head permeability]) on July 15, 1998. Geotechnical soil samples were composited from three locations in each landfill cell, an undisturbed area north of Landfill A9-1, and the Sandia Borrow Pit. Geotechnical test results are summarized in Table 1 and can be found in Appendix B.

The existing soil landfill caps consist of sands with silt and minor gravel (see sieve analysis results [ASTM, 1997c] in Appendix B). The maximum density (ASTM, 1997d) of the existing caps ranged from $1,822.8 \mathrm{~kg} / \mathrm{m}^{3}\left(113.8 \mathrm{lb} / \mathrm{ft}^{3}\right)$ to $1,986.2 \mathrm{~kg} / \mathrm{m}^{3}\left(124.0 \mathrm{lb} / \mathrm{ft}^{3}\right)$. The maximum density of native, undisturbed soil north of Landfill A9-1 was $1,665.9 \mathrm{~kg} / \mathrm{m}^{3}\left(104.0 \mathrm{lb} / \mathrm{ft}^{3}\right)$. The maximum densities were used to determine the percent compaction from the field density tests (ASTM, 1997a) and the density to mold the permeability samples to be representative of in-situ conditions.

The permeability samples were composited from three sample points. They were molded in the Bechtel Nevada Materials Testing Laboratory located in Mercury, Nevada at the approximate average wet density of the soil sample points to be representative of in-situ conditions. The permeabilities were $2.84 \times 10^{-6}$ centimeters $/ \mathrm{second}(\mathrm{cm} / \mathrm{sec})\left(\right.$ Landfill A9-1), $1.53 \times 10^{-4} \mathrm{~cm} / \mathrm{sec}$ (Landfill A9-2), and $1.60 \times 10^{-4} \mathrm{~cm} / \mathrm{sec}$ (Landfill A9-3). The native soil sample collected north of Landfill A9-1 has a higher permeability than the existing landfill caps by approximately an order of magnitude $\left(5.06 \times 10^{-3} \mathrm{~cm} / \mathrm{sec}\right)$. The permeability samples collected from the Sandia Borrow Pit were molded at approximately 85, 90, and 95 percent of the maximum density since compaction results achieved during the closure activities at CAU 404 (Roller Coaster Sewage Lagoons and North Disposal Trench) and CAU 426 (Cactus Spring Waste Trenches) were within this range. The permeability of the Sandia Borrow Pit soil were $8.82 \times 10^{-4} \mathrm{~cm} / \mathrm{sec}(85.6$ percent compaction), $3.80 \times 10^{-5} \mathrm{~cm} / \mathrm{sec}\left(91.1\right.$ percent compaction), and $1.39 \times 10^{-5} \mathrm{~cm} / \mathrm{sec}(96.5$ percent compaction). The Sandia Borrow Pit soil permeability when compacted to 85 to 95 percent is up to an order of magnitude lower than the permeability of the existing covers at Landfills A9-2 and A9-3 and is up to approximately an order of magnitude higher than the existing cover at 
TABLE 1 -- SUMMARY OF GEOTECHNICAL TEST RESULTS

\begin{tabular}{|c|c|c|c|c|c|}
\hline $\begin{array}{r}\text { SAMPLE } \\
\text { LOCATION } \\
\hdashline \\
\hdashline \\
\hdashline\end{array}$ & $\begin{array}{l}\text { SAMPLE } \\
\text { NUMBER } \\
\therefore: \cdots \\
\because \cdots\end{array}$ & $\begin{array}{c}\text { MAXIMUM } \\
\text { DENSITY } \\
\text { Kg/m } \\
\left(\mathrm{lbs} / \mathrm{ft}^{3} \mathbf{t}^{3}\right)\end{array}$ & $\begin{array}{l}\text { AVERAGE } \\
\text { PERCENT } \\
\text { COMPACTION } \\
\text { (Compaction } \\
\text { Test in field) }\end{array}$ & 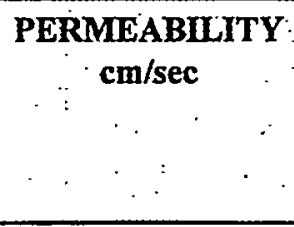 & $\begin{array}{c}\text { PERCENT } \\
\text { COMPACTION } \\
\text { (Remolded } \\
\text { Permeability } \\
\text { Sample) } \\
\end{array}$ \\
\hline $\begin{array}{l}\text { Native soil } \\
\text { north of A9-1 }\end{array}$ & $\mathrm{A} 9 / 4 \mathrm{ABC}$ & $\begin{array}{l}1665.9 \\
(104.0)\end{array}$ & 89.9 & $5.06 \mathrm{E}-03$ & 92.6 \\
\hline A9-1 Cap & $\mathrm{A} 9 / 3 \mathrm{ABC}$ & $\begin{array}{c}1986.2 \\
(124.0)\end{array}$ & 84.7 & $2.84 \mathrm{E}-06$ & 84.9 \\
\hline A9-2 Cap & $\mathrm{A} 9 / 2 \mathrm{ABC}$ & $\begin{array}{l}1946.2 \\
(121.5)\end{array}$ & 80.4 & $1.53 \mathrm{E}-04$ & 80.2 \\
\hline A9-3 Cap & $\mathrm{A} 9 / 1 \mathrm{ABC}$ & $\begin{array}{l}1822.8 \\
(113.8)\end{array}$ & 85.7 & $1.60 \mathrm{E}-04$ & 85.7 \\
\hline $\begin{array}{l}\text { Sandia } \\
\text { Borrow Pit }\end{array}$ & Borrow & $\begin{array}{l}2034.3 \\
(127.0)\end{array}$ & $\begin{array}{l}\text { N/A } \\
. .\end{array}$ & 8.82E-04 & 85.6 \\
\hline $\begin{array}{l}\text { Sandia } \\
\text { Borrow Pit }\end{array}$ & Borrow & $\begin{array}{l}2034.3 \\
(127.0)\end{array}$ & N/A & $3.80 \mathrm{E}-05$ & 91.1 \\
\hline $\begin{array}{l}\text { Sandia } \\
\text { Borrow Pit }\end{array}$ & Borrow & $\begin{array}{l}2034.3 \\
(127.0)\end{array}$ & N/A & 1.39E-05 & 96.5 \\
\hline
\end{tabular}




\section{Landfill A9-1.}

Three compaction tests (field density tests) were conducted in each landfill cell and the native, undisturbed soil north of Landfill A9-1. The average compaction results were similar between the landfill cells and the native, undisturbed area north of Landfill A9-1 (ranged from 80.4 percent [Landfill A9-2] to 89.9 percent compaction [native, undisturbed area north of Landfill A9-1]).

The existing landfill cap thicknesses were determined during the site investigation activities in 1997 (Luke, et al., 1997). The Landfill A9-1 cap ranged from approximately $0.2 \mathrm{~m}(0.7 \mathrm{ft})$ to 0.7 $\mathrm{m}(2.3 \mathrm{ft})$. The caps at Landfills A9-2 and A9-3 were approximately $0.3 \mathrm{~m}(1.0 \mathrm{ft})$.

Alternative 2 (Administrative Controls) was selected based upon:

- The detailed and comparative evaluation of alternatives presented in the CADD (DOE, 1998).

- Inadvertent intrusion and contact with the solid waste and potentially live UXO would be prevented during and after implementation.

- No hazardous waste was encountered below the landfill cells in the 1997 investigation activities.

- . Surface or subsurface disturbances during the implementation of other remedial alternatives (installation of additional capping material or clean closure) would greatly increase the risk to site worker safety from the potential detonation of UXO.

Administrative Controls consists of the following activities:

- Backfill and grade the open portion of Cell A9-1.

- Install warning signs, perimeter fencing, and/or monuments.

- Enact use restrictions.

\subsubsection{Backfilling and Grading the Open Portion of Cell A9-1}

Critical locations such as corners of all three cells and the open portion of Cell A9-1 will be staked and surveyed for as-built documentation and land-use restrictions. During field activities, 
cell boundaries will be clearly delineated with brightly-colored rope or chain to prevent inadvertent access. All site personnel will be instructed to avoid potential UXO debris and areas of potential live UXO.

The northeast end of Cell A9-1 is an open depression which was cleared of all debris in 1995 (DOE, 1997). The open portion will be backfilled with soil from the Sandia Borrow Pit located southwest of the site. The backfill will be placed in 0.2 meter (m) (8 inch [in]) lifts, and compacted by the field equipment. Precautions will be taken to prevent personnel and equipment working in the open portion from contacting the covered portion immediately to the southwest. Backfill to be in contact with the covered portion will be pushed or dropped into place and not compacted. The edge of the covered portion will be delineated with a brightly-colored rope or chain and a site worker will be dedicated to constantly monitor this sensitive area whenever there are work activities in the immediate area. The monitor will be equipped with a warning horn to alert workers who are about to contact the covered portion. In order to account for gradual settling and consolidation of the uncompacted backfill, the uncompacted backfill will be mounded up to $1.0 \mathrm{~m}$ (3.3 feet [ft]) above grade, approximately one-third the depth of backfill below grade.

Based on information in the CADD (DOE, 1998), the open portion of Cell A9-1 is approximately

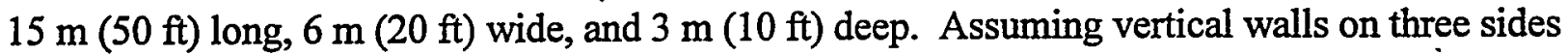
and the bottom rising to the existing ground surface at the northeast end, the approximate volume of the surface depression is 135 cubic meters $\left(\mathrm{m}^{3}\right)\left(177\right.$ cubic yards $\left.\left[\mathrm{yd}^{3}\right]\right)$.

Standard construction equipment will be used for loading, moving, compaction, and grading activities. Equipment may consist of, but will not be limited to a front-end loader, sheeps-foot compactor, vibratory roller, and water truck. Backfill will be obtained from the soil stockpile

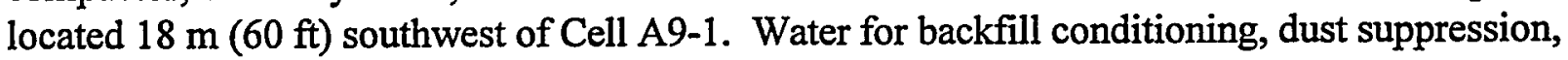
and other construction activities will be obtained from the Roller Coaster Well located approximately $14 \mathrm{~km}(9 \mathrm{mi})$ west of the site (Figure 1).

\subsubsection{Installation of Fencing, Warning Signs, and Monuments}

To inhibit inadvertent site entry, a perimeter chain-link fence will be installed with at least three $\mathrm{m}(10 \mathrm{ft})$ of clearance beyond cell boundaries to allow for equipment access.

Warning signs will be posted on the fence at intervals of 15 to $30 \mathrm{~m}$ ( 50 to $100 \mathrm{ft}$ ) with the following information:

- Landfill identification (for example, "CAU 453 - Area 9 UXO Landfill”). 
- Warning (for example, "Danger, Potential Unexploded Ordnance").

- Instructions (for example, "Contact [office] at [phone no.] before entering this site, digging or trenching in this site, or removing this sign").

At the beginning of field activities, the cell locations will be marked with monuments placed either at actual cell boundary corners, or set back at a consistent distance to provide a safety margin, $1 \mathrm{~m}(3.3 \mathrm{ft})$ for example. During field activities, bright orange or yellow rope or chain will be strung between monuments to further denote cell boundaries. Additional monuments may be necessary at intermediate locations between cell corners. The monument posts will be embedded in the ground and constructed of concrete. The fence, signs, and monuments are intended to last at least 30 years and will require periodic maintenance and replacement.

\subsubsection{Implementation of Administrative Controls to Restrict Use}

Administrative controls will be used to restrict use on the CAU 453 site through coordination with TTR administrative, maintenance, and operational organizations. Coordination of the closure will include the U. S. Air Force because of the location of the site and use status. The future use of any land related to this CAU will be restricted from activities that may alter or modify the containment control as identified in the Closure Report, unless appropriate concurrence is obtained in advance. Administrative controls should be effective because the -TTR is a restricted access facility.

\subsection{CONSTRUCTION QUALITY ASSURANCE / QUALITY CONTROL}

The native, undisturbed soil density is estimated to be approximately 80 percent of the maximum density. Excluding the backfill over the UXO interface zone, the backfill material will be compacted to a minimum of 80 percent of maximum density. Prior to implementing field activities, at least one maximum density (Proctor) test (ASTM, 1997d) will be done on the backfill material to determine its maximum density. A minimum of four field nuclear-density tests (ASTM, 1997a) will then be done at the beginning of compaction activities on lifts of $0.2 \mathrm{~m}$ ( 8 in). The number of passes of compaction equipment over the lift, needed to compact the lift to at least 80 percent maximum density will be the field performance specification. Additional field tests will be done periodically during compaction activities to confirm or modify the field performance specification so that a compaction of at least 80 percent maximum density is achieved. A minimum of four field tests will be done in an intermediate lift, in the final lift, and 
whenever changes occur in the backfill material (such as significant visual change in the grain size distribution).

\subsection{WASTE MANAGEMENT}

Resource Conservation and Recovery Act (RCRA), hydrocarbon, and hazardous wastes are not expected to be generated. Nonhazardous solid wastes are expected to be generated and may include construction debris from fence and monument installation activities. If hydrocarbon or hazardous wastes are generated, the wastes will be managed and disposed of in accordance with U.S. DOE orders, U.S. Department of Transportation requirements, state and federal regulations, and agreements and permits between DOE/Nevada Operations Office and the NDEP.

Construction debris will be disposed in a TTR or Nevada Test Site landfill. 


\subsection{SCHEDULE}

The following schedule is anticipated for TTR Area 9 UXO Landfill CAU 453 closure activities:

- Begin TTR Area 9 UXO Landfill field closure activities within 60 calendar days from the date that NDEP grants approval of the CAP.

- Complete field closure activities for TTR Area 9 UXO Landfill within 60 calendar days after beginning field closure activities.

- $\quad$ Prepare the Closure Report for submittal to NDEP within approximately 120 calendar days after completion of field closure activities.

Flexibility has been placed in the project schedule to account for minor difficulties (weather, equipment breakdowns, etc.). DOE will keep the NDEP apprised of any condition that may impact the project schedule. 


\subsection{POST-CLOSURE MONITORING PLAN}

A post-closure monitoring of the Area 9 UXO Landfill is proposed and will consist of biannual (twice per year) visual inspections to verify that the soil covers remain intact and level, warning signs and monuments are in place and readable, and use restrictions are maintained. Additional, nonscheduled inspections may be required after severe weather events such as heavy rainfall, flash flooding, and high winds. Any identified maintenance and repair requirements will be remedied within 90 calendar days of discovery and documented in writing at the time of repair. The biannual inspections will be performed for approximately five years after site closure, and will be documented on inspection forms.

The proposed monitoring plan includes an annual report, which will describe observations, modifications, and/or repairs made to the cover and cover area. The annual report will be prepared following the second inspection of each year that post-closure monitoring is conducted. The annual reports will include the following information:

- Discussion of observations.

- Inspection checklist and maintenance record.

- Conclusions and recommendations.

A copy of each annual report will be submitted to the NDEP. 


\subsection{REFERENCES}

\section{American Society for Testing and Materials, see ASTM}

ASTM, 1997a, Method D 2922-91: Standard Test Methods for Density of Soil and SoilAggregate in Place by Nuclear Methods (Shallow Depth), 1997 Annual Book of ASTM Standards, Volume 04.08, Soil and Rock (I): D 420 - D 4914.

ASTM, 1997b, Method D 2434-68: Standard Test Method for Permeability of Granular Soils (Constant Head), 1997 Annual Book of ASTM Standards, 'Volume 04.08, Soil and Rock (I): D 420 - D 4914.

ASTM, 1997c. Method D 422-90: Standard Test Method for Particle-Size Analysis of Soils, and Method D 1140-92: Standard Test Method for Amount of Material in Soils Finer Than the No. 200 Sieve, 1997 Annual Book of ASTM Standards, Volume 04.08, Soil and Rock (I): D 420 - D 4914.

ASTM, 1997d, Method D 1557-91: Standard Test Method for Laboratory Compaction Characteristics of Soil Using Modified Effort, 1997 Annual Book of ASTM Standards, Volume 04.08, Soil and Rock (I): D 420 - D 4914.

DOE, 1995, Voluntary Corrective Action Plan For Ordnance Removal From Five Disposal Sites At The Tonopah Test Range, DOE/NV-386 UC-700.

DOE, 1996, Nevada Environmental Restoration Project, Health and Safety Plan.

DOE, 1996, Nevada Environmental Restoration Project. Industrial Sites, Quality Assurance Project Plan, Nevada Test Site, Rev. 1, DOE/NV-425.

DOE, 1997, Corrective Action Investigation Plan For CAU No. 453: Area 9 Landfill, Tonopah Test Range, DOE/NV-475 UC-700.

DOE, 1998, Corrective Action Decision Document For The Area 9 UXO Landfill, Tonopah Test Range, CAU 453, DOE/NV-497 UC-700.

EPA, 1996, Region IX Preliminary Remediation Goals (PRGs), San Francisco, CA. 
Luke, B. A., Stone, R., Hartzell, L., 1997. Seismic Surface Wave Measurements at the Area 9 Landfill Complex, Tonopah Test Range, Nevada. University of Nevada, Las Vegas, July 11, 1997.

NDEP, 1998, July 13, 1998 Letter from Karen K. Beckley to Runore C. Wycoff, RE: Draft CAP for CAU 453: Area 9 UXO Landfill, TTR, June 1998.

Nevada Division of Environmental Protection, see NDEP

U.S. Department of Energy, see DOE

U.S. Environmental Protection Agency, see EPA 


\section{APPENDIX A}

\section{ENGINEERING DRAWINGS}




\title{
UNITED STATES DEPAR'
}

\author{
$N E \vee A D A \quad O P E R A T$ I $O$
} LAS VEGAS,

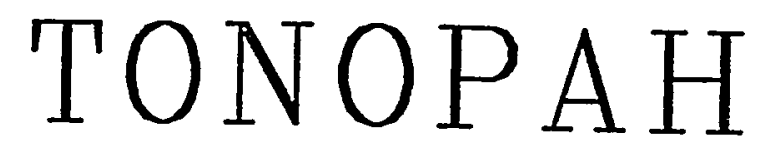

AREA

\section{9}

LA

A

$\mathrm{ND}$

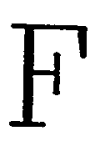

ILL

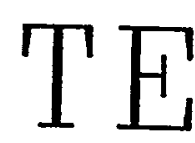

$\mathrm{H}$

DUER
DRAYING TITLE

SCOPE OP TORK

THIS PRONECT INCLLDES THE RESTORATION OF 1 EXISTING LANDFILL LOCATION.

WOFX ILL PRJRURILY INYVQVE FILLING OF LOCAL SUPRACE DEPRESSION WIJH

NATIVE SOILS. AND INSTALLATION OF NEF FENCE AROND ENTIRE SITE.

AREA EVALUATION FOR RESIOUAL SOIL CONTAMIMATION SHALL BE PERFORLED GY

THE COMTRACTOR IN ACCORDANCE YITH DDENN S480.11 AND THE CONTRACTOR'S

PROCEDRES PRIOR TO COWENEINE CONSTRUCTIDH ACTIVITIES

PROJECT NOTBS

ALL CONSTRUCTION FEATURES. MATERIMLS. TESTS AND DETAILS SHALL CONFORM TO

THIS PROCET SEE THE ITSS OVEREAD POgA. FOR STMNOAROS

THE RSH DESIGN DRAWING STMIDARDS. 


\section{MENT OF ENERGY}

$N S \quad O F F$ I $C E$

E $V A D A$

T RANGE

OSURE CAU 453

52

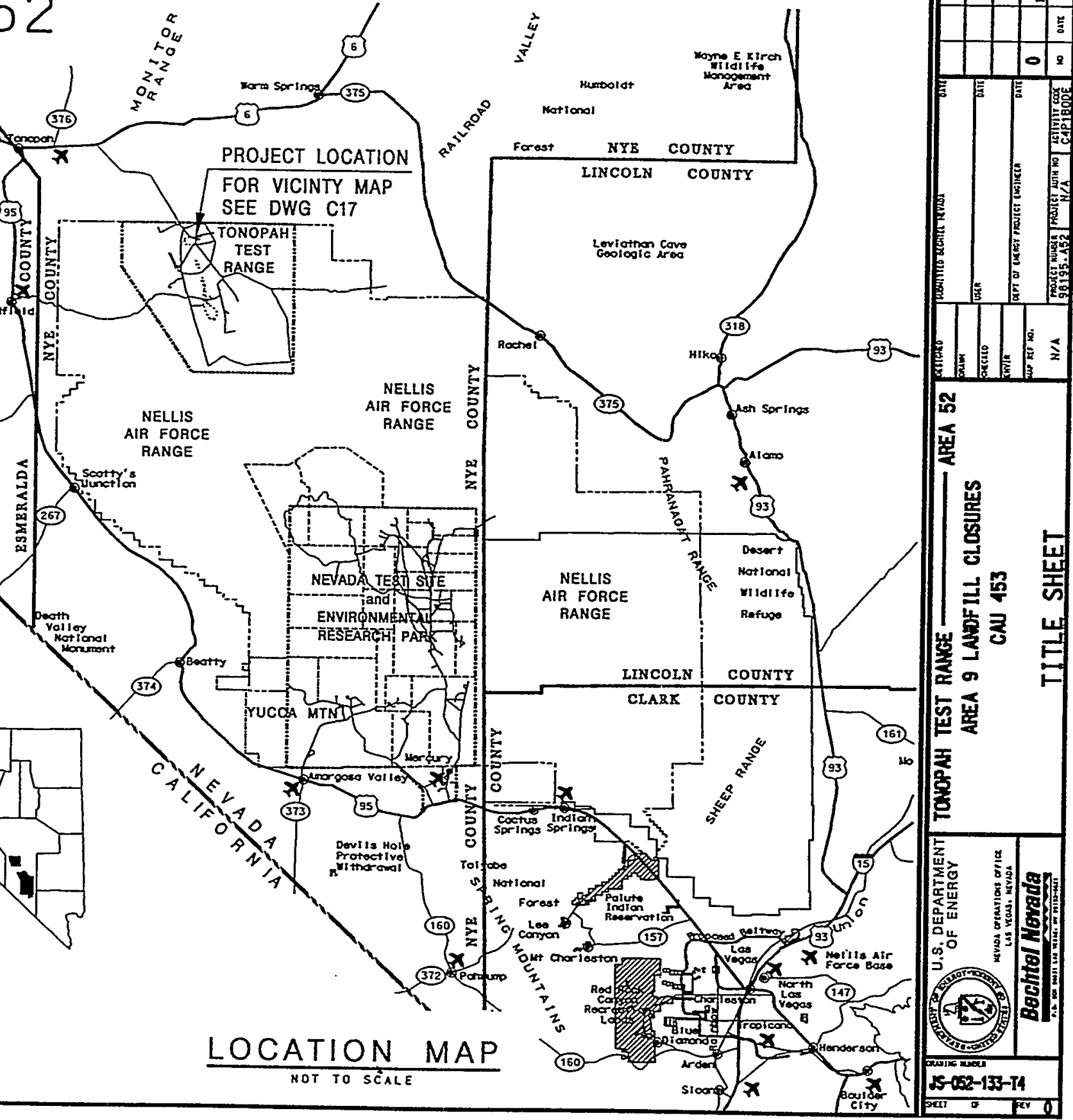




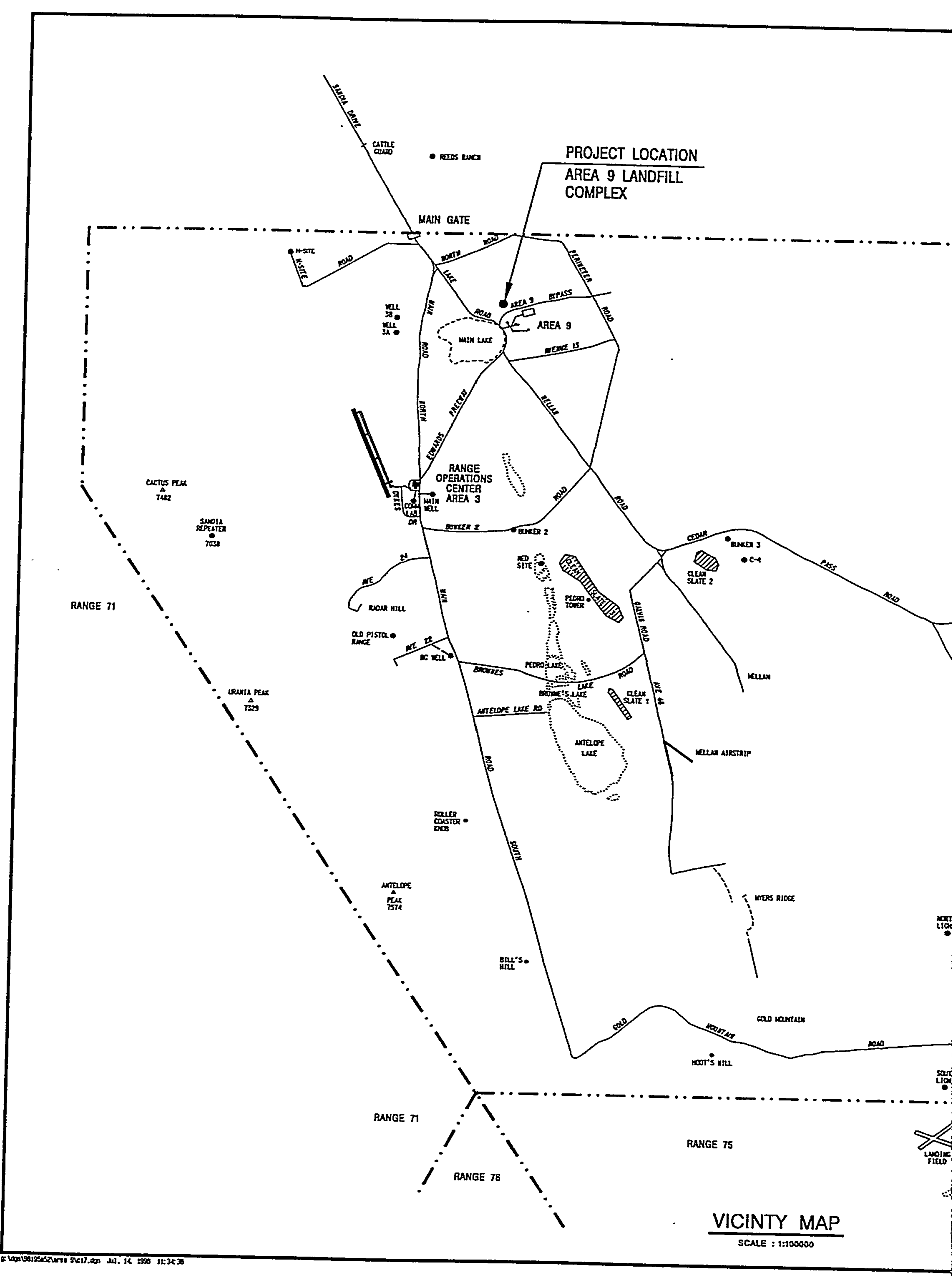




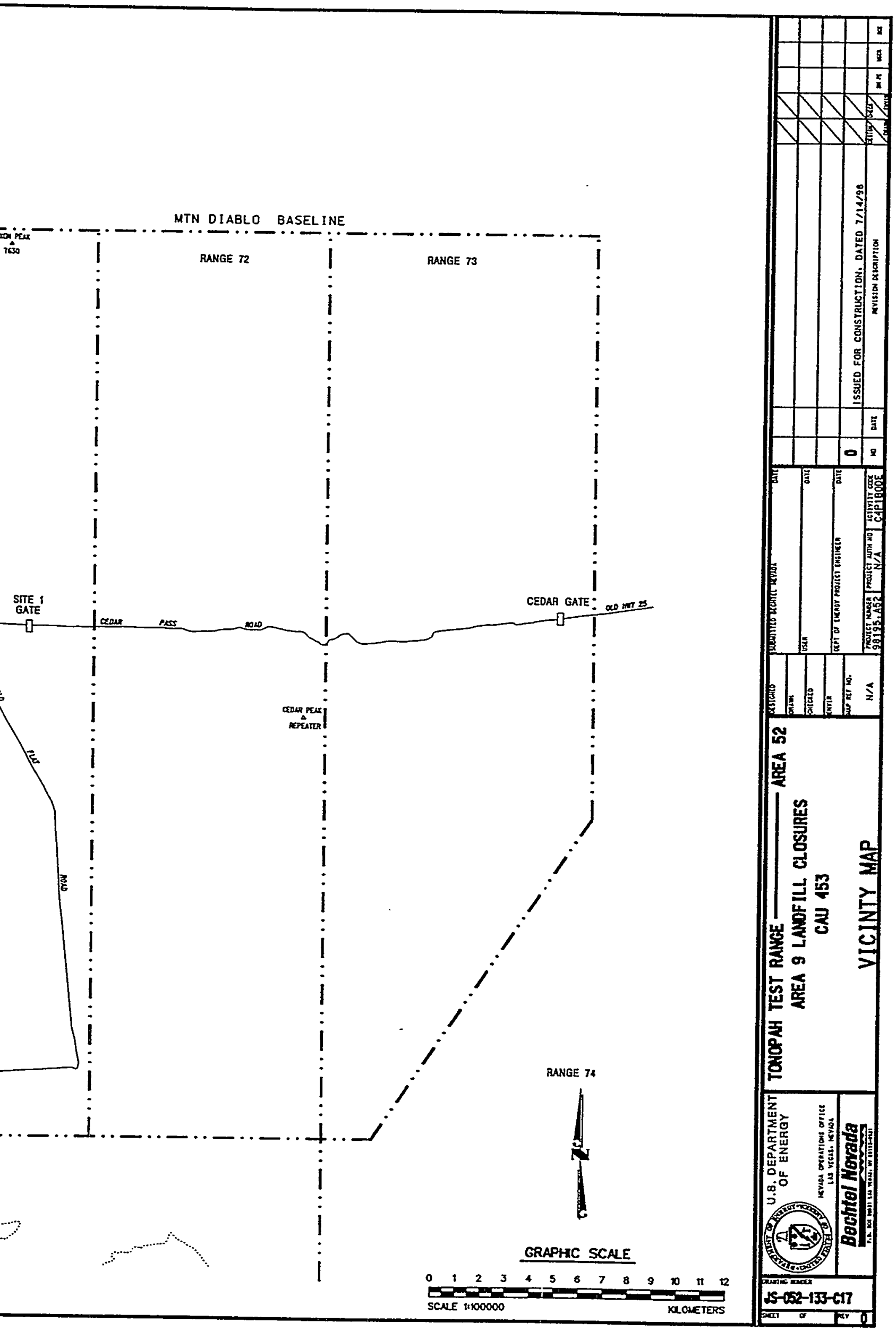




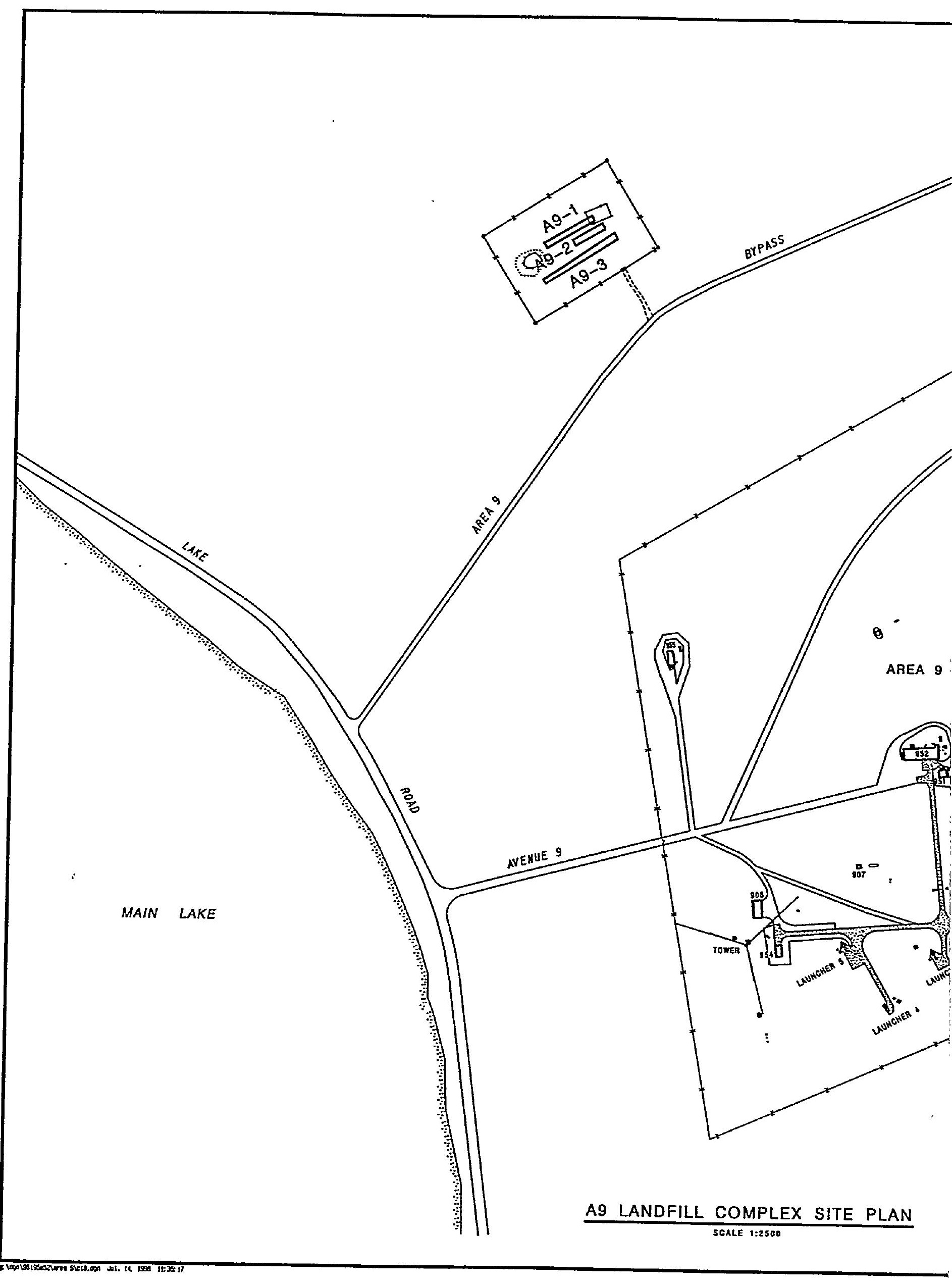




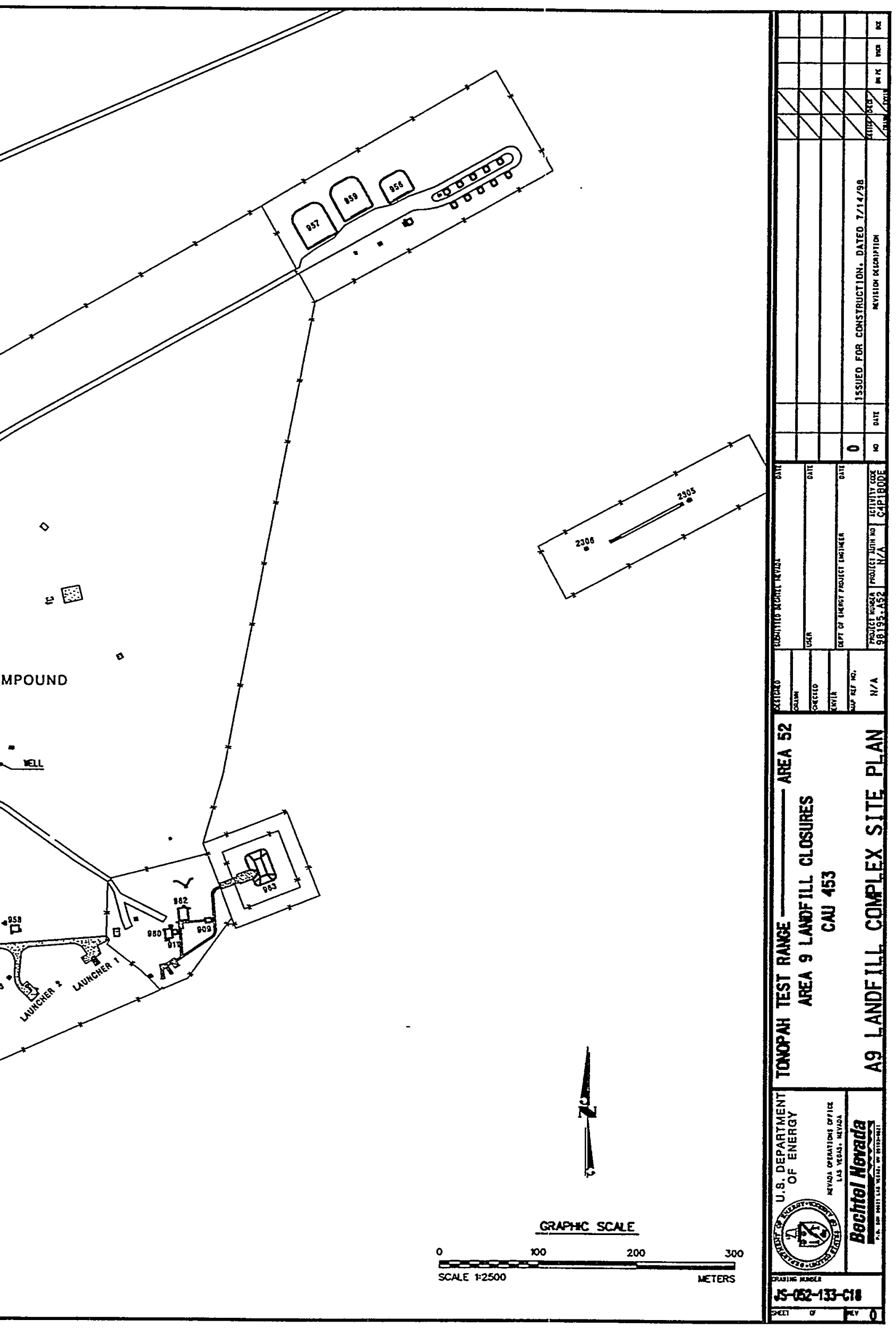




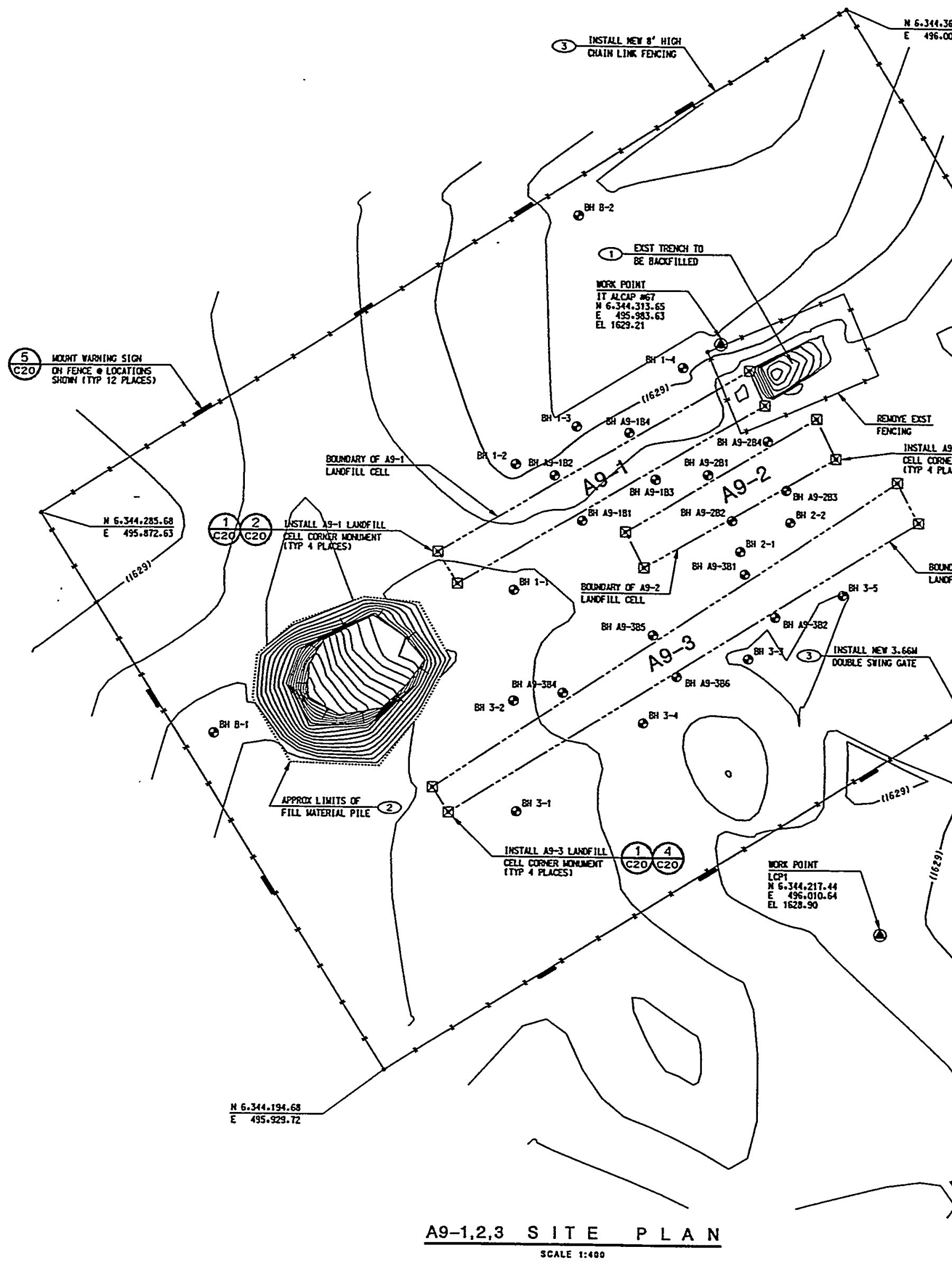




\section{KEY NOTES}

(D) FILL EXISTING OPEX PORTION OF TRENCH.

(2) EXISTIMG STOCXPILE TO BE USED FOR FILL.

(3) FOR FEMCING AMD GATE DETAILS SEE RSK

N O T E S

i. OEPRESSIOKS TITHIN LAMDFILL CELLS SHALL QE FILLED ANO

2. TREMCHES COHTAIH UXO. HEAVY EOUIPUEMT TO REWAIM

3. ALL FILL SHALL BE COMPACTED TO 802 OF HAXIMUU DENSITY

1. FOR YORE SPECIFIC PROSECT REQUIREMENTS AND

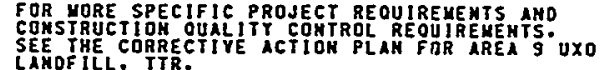

$8^{8+3-3}$
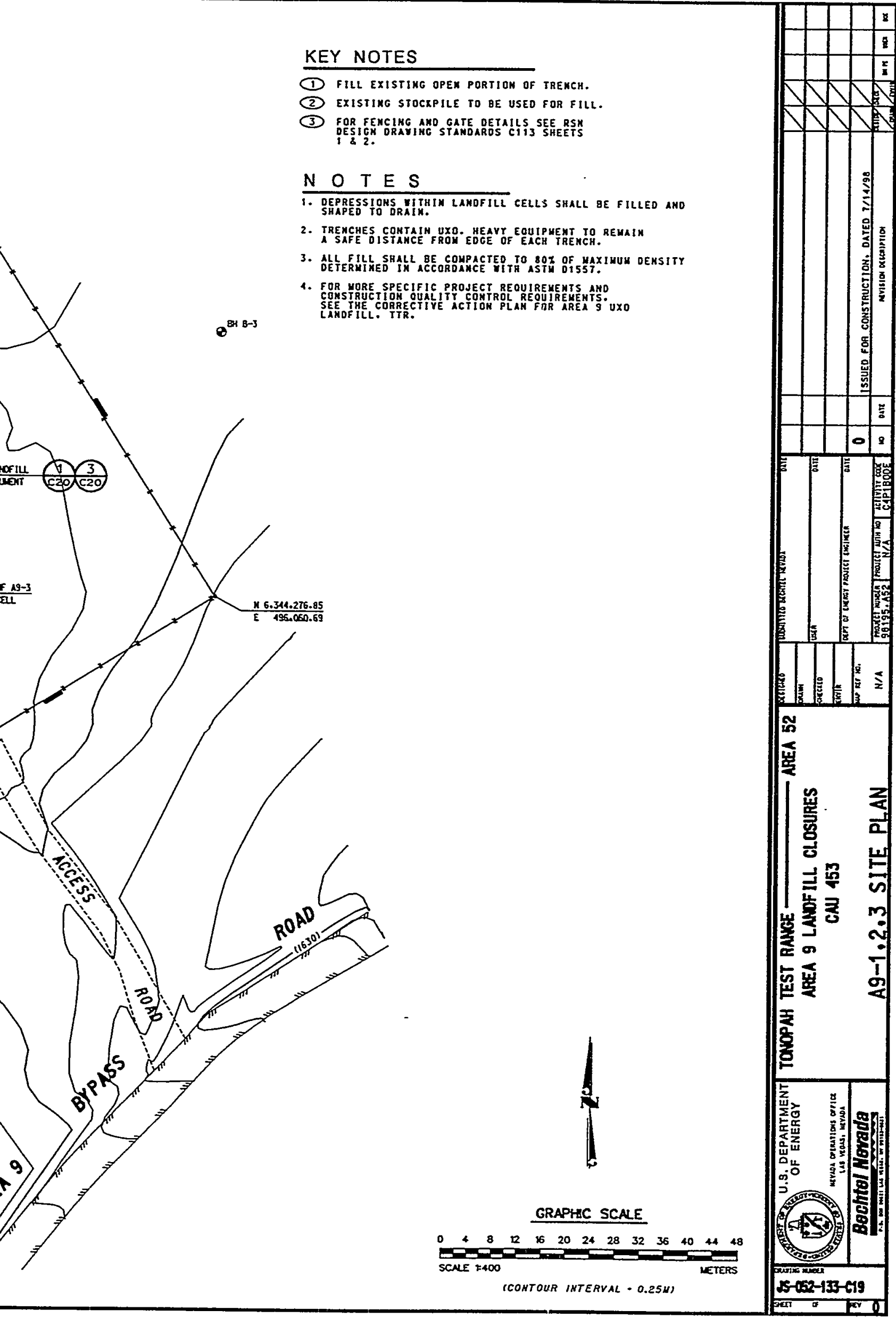


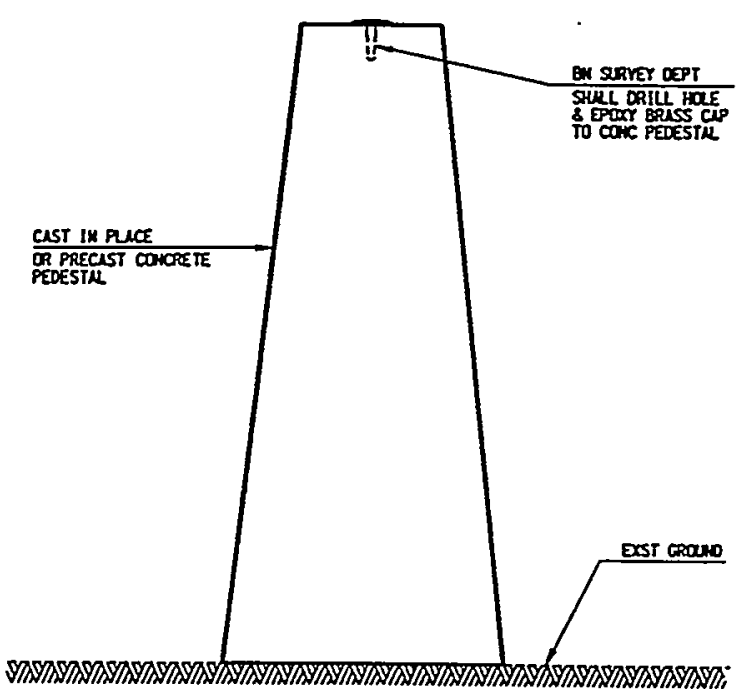

MONUMENT DETAIL NOT TO SCNLE
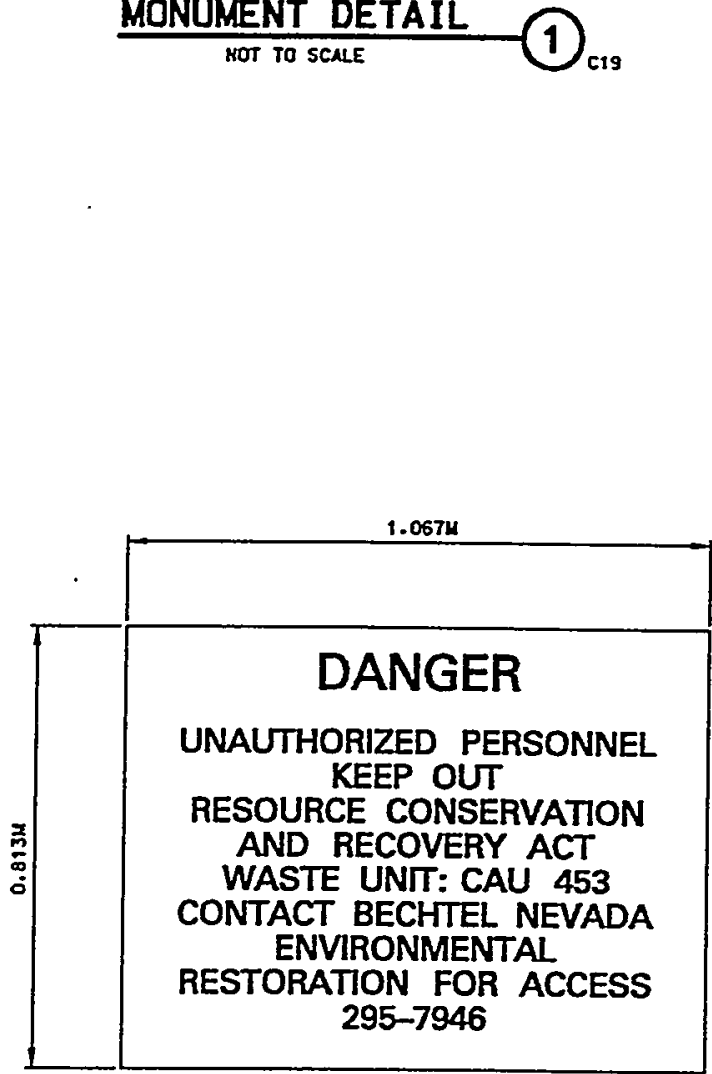

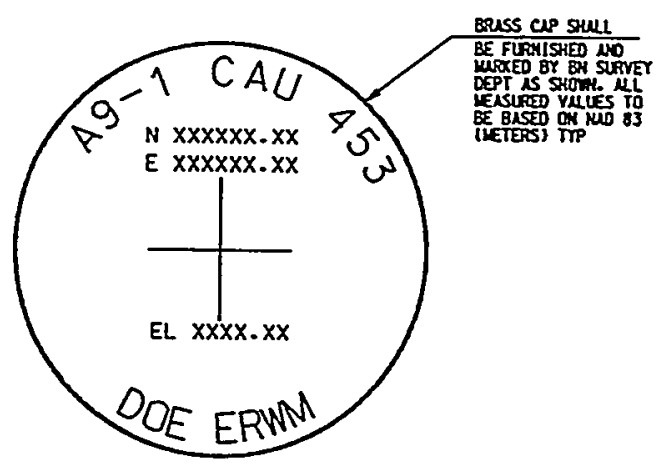

MARKER DETAIL NOT TO SCNLE
SIGN DETAIL

NoT TO SCME 

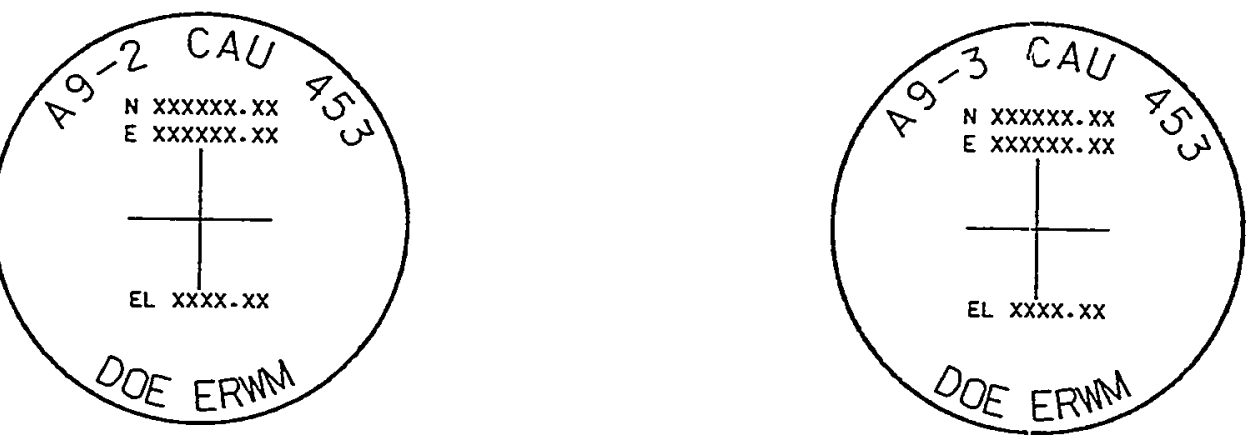

MARKER DETAIL

(3)

MARKER DETAIL

NOT TO SCNLE

(4)

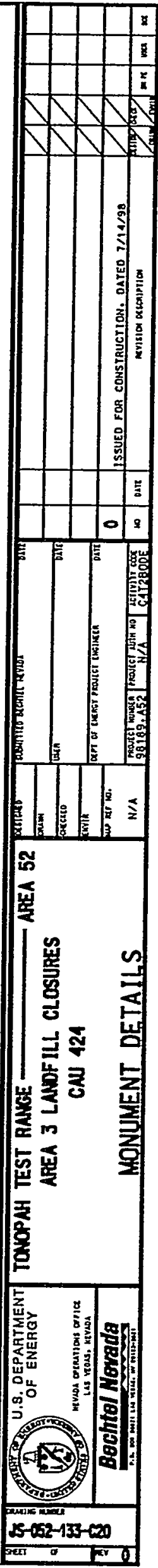




\section{APPENDIX B}

\section{GEOTECHNICAL TEST RESULTS}




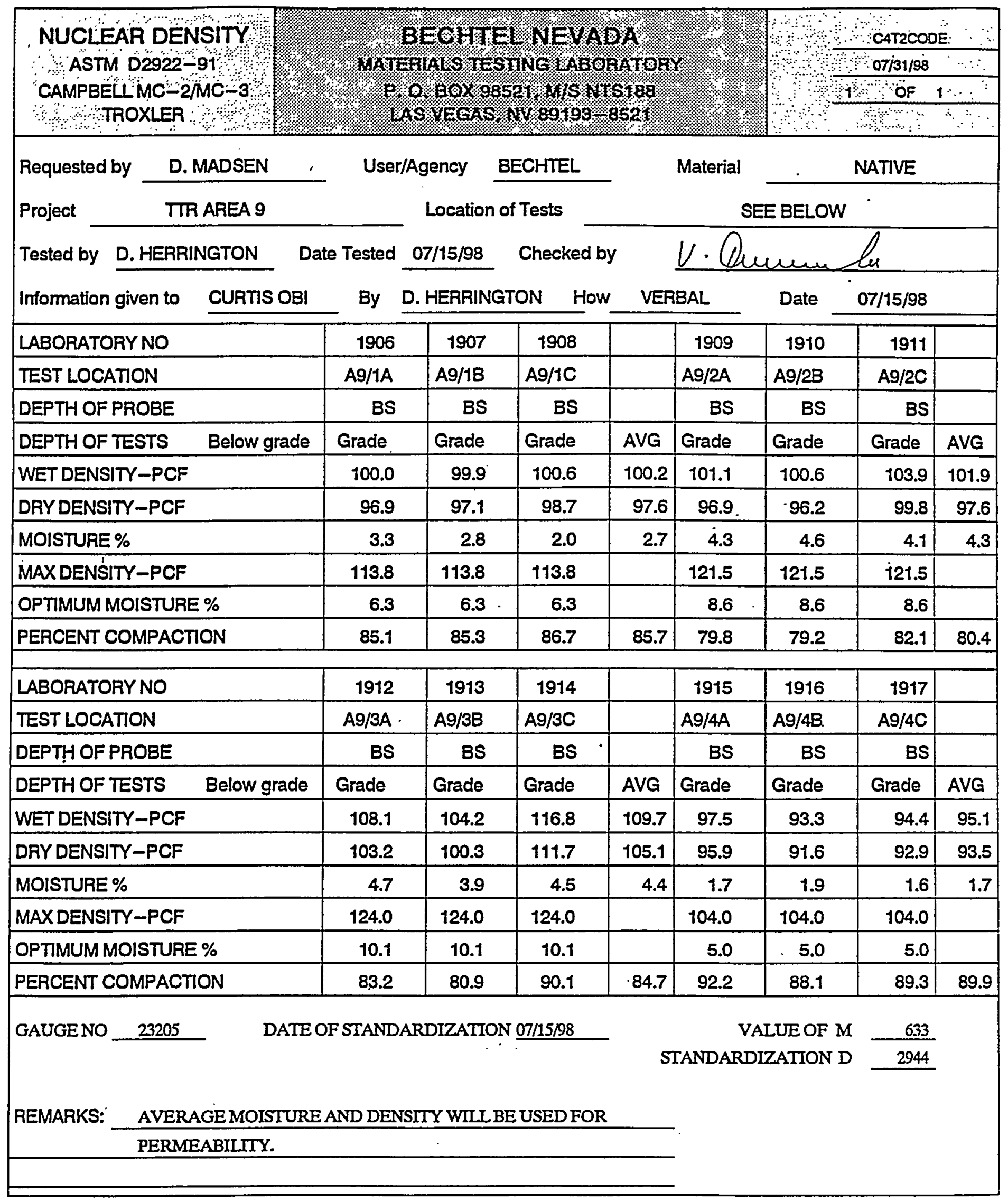




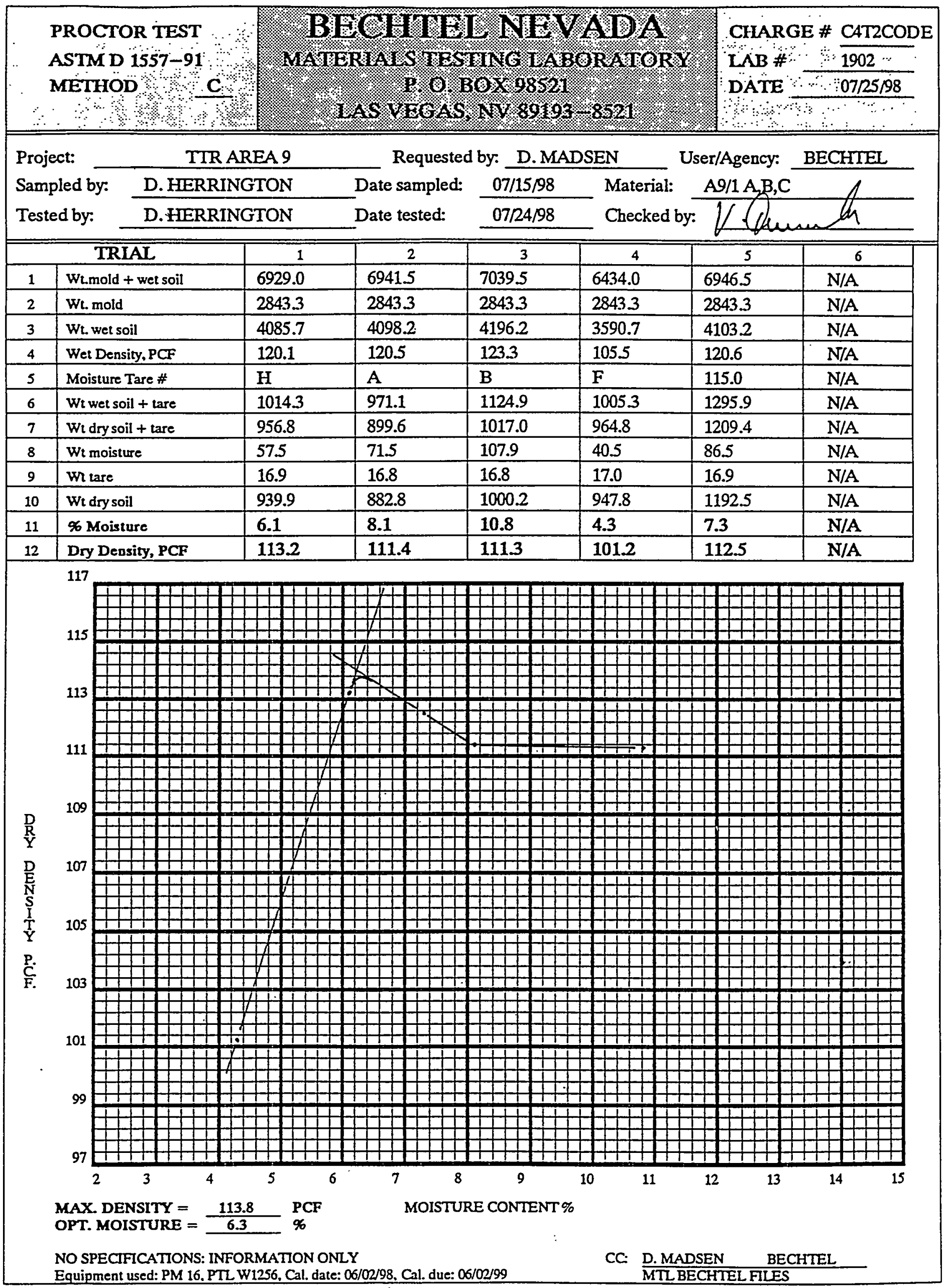




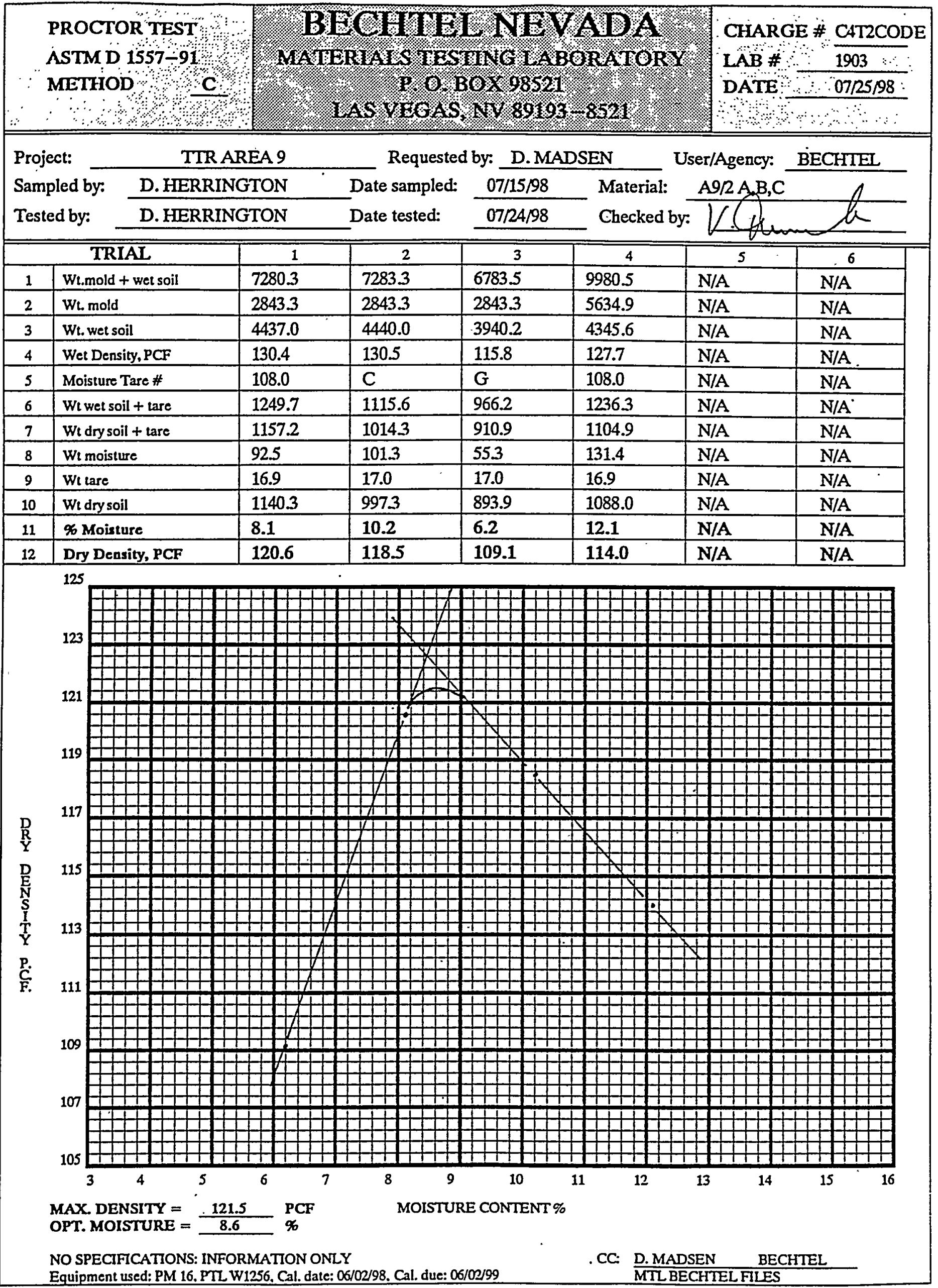




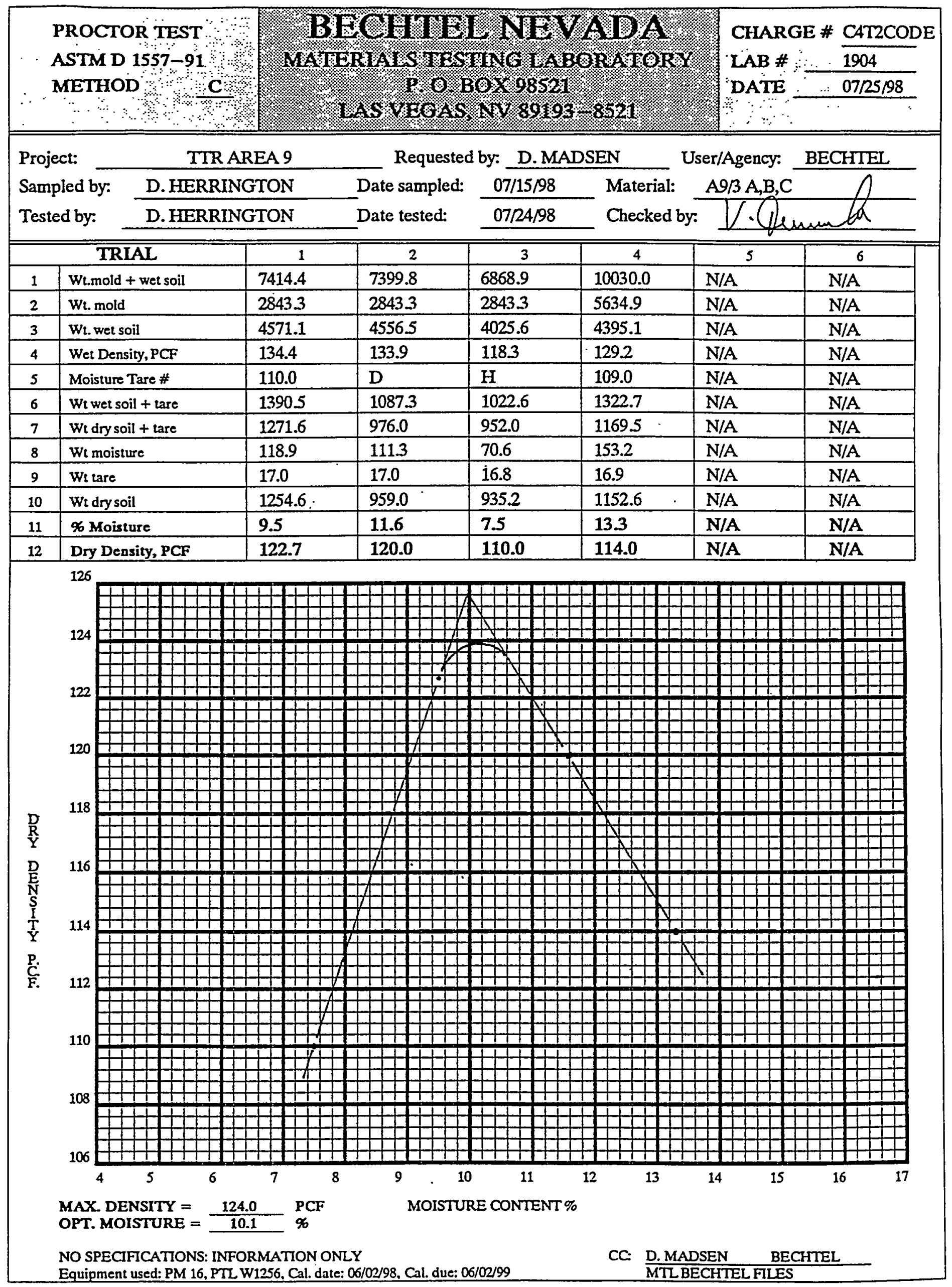


PROCTORTEST

ASTM D 1557 $\div 91$

MËTHOD
BEC HMUL NEWADA

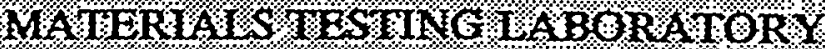

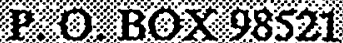

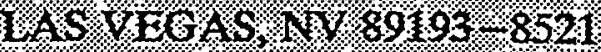

CTHARGE \# CAT2CODE

LAB \# 1905

DATE O07/25/98

\begin{tabular}{|c|c|c|c|c|c|c|c|c|}
\hline \multirow{3}{*}{\multicolumn{2}{|c|}{$\begin{array}{l}\text { Project: } \\
\text { Sampled by: } \\
\text { Tested by: }\end{array}$}} & \multicolumn{2}{|c|}{ TTR AREA 9} & \multicolumn{3}{|c|}{ Requested by: D.MADSEN } & \multirow{2}{*}{$\begin{array}{l}\text { User/Agency: } \\
\text { A9/4 A,B,C }\end{array}$} & \multirow{2}{*}{$\frac{\text { BECHIEL }}{\cdot}$} \\
\hline & & \multirow{2}{*}{\multicolumn{2}{|c|}{$\begin{array}{l}\text { D. HERRINGTON } \\
\text { D. HERRINGTON }\end{array}$}} & \multirow{2}{*}{$\begin{array}{l}\text { Date sampled: } \\
\text { Datè tested: }\end{array}$} & \multirow{2}{*}{$\begin{array}{l}07 / 15 / 98 \\
07 / 24 / 98\end{array}$} & \multirow{2}{*}{$\begin{array}{l}\text { Material: } \\
\text { Checked by }\end{array}$} & & \\
\hline & & & & & & & & $b$ \\
\hline \multicolumn{3}{|c|}{ TRIAL } & 1 & 2 & 3 & 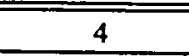 & 5 & 6 \\
\hline 1 & \multicolumn{2}{|c|}{ WL.mold + wet soil } & 6526.1 & 6410.0 & 6291.4 & 6516.4 & N/A & N/A \\
\hline 2 & \multicolumn{2}{|c|}{ WL. mold } & 2843.3 & 2843.3 & 2843.3 & 28433 & N/A & N/A \\
\hline 3 & \multicolumn{2}{|c|}{ Wt. wet soil } & 3682.8 & 3566.7 & 3448.1 & 3673.1 & N/A & N/A \\
\hline 4 & \multicolumn{2}{|c|}{ Wet Density, PCF } & 108.3 & 104.8 & 101.4 & 108.0 & N/A & N/A \\
\hline 5 & \multicolumn{2}{|c|}{ Moisture Tare \# } & 111.0 & $\mathrm{E}$ & 110.0 & 114.0 & N/A & N/A \\
\hline 6 & \multicolumn{2}{|c|}{ Wh wel soil + tare } & 1119.5 & 1002.2 & 890.6 & 887.0 & N/A & N/A \\
\hline 7 & \multicolumn{2}{|c|}{ Wt dry soil + tare } & 1071.1 & 941.0 & 867.4 & 840.5 & N/A & N/A \\
\hline 8 & \multicolumn{2}{|c|}{ Wt moisture } & 48.4 & 61.2 & 23.2 & 46.5 & N/A & N/A \\
\hline 9 & \multicolumn{2}{|l|}{ Wh tare } & 17.0 & 17.0 & 16.9 & 16.9 & N/A & N/A \\
\hline 10 & \multicolumn{2}{|c|}{ We dry soil } & 1054.1 & 924.0 & 850.5 & 823.6 & N/A & N/A \\
\hline 11 & \multicolumn{2}{|c|}{ \% Moisture } & 4.6 & 6.6 & 2.7 & 5.6 & N/A & N/A \\
\hline 12 & \multicolumn{2}{|c|}{ Dry Deasity, PCF } & 103.5 & 98.3 & 98.7 & 102.2 & N/A & N/A \\
\hline
\end{tabular}

106

105

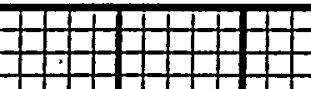

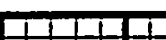

\section{$(0-100$}

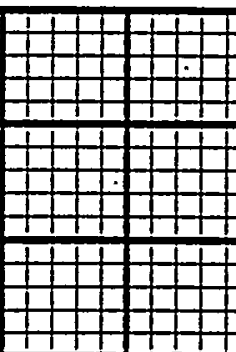

103

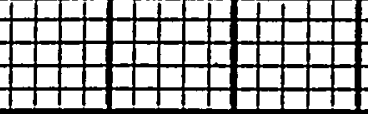

104

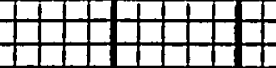

HNOH

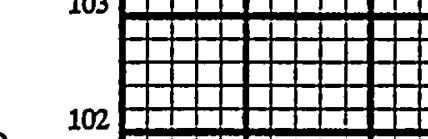

$\underset{\mathbf{R}}{\mathrm{R}}$

D

N

$\underset{T}{\mathrm{~T}}$

P.

101

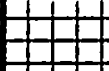

98

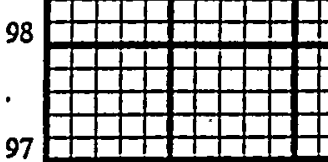

97
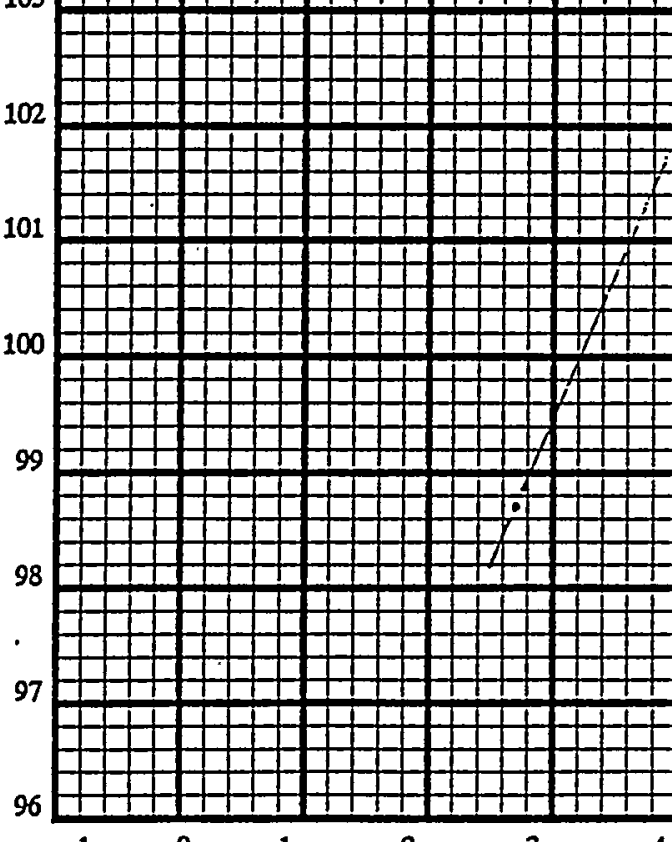

- 0 - $+40+2$

$2010-1100$

$+1+1$

96

$-1 \quad-0$

2

3

4

5

6

7

8

9

10

11

MAX. DENSITY $=104.0$ PCF MOISTURE CONTENT\%

OPT. MOISTURE $=\frac{104.0}{5.0} \%$

NO SPECIFICATIONS: INFORMATION ONLY

Equipment used: PM 16, PTL W1256. Cal. date: 06/02/98. Cal. due: 06/02/99
CC. D. MADSEN BECHTEL MTLBECHTELFILES 


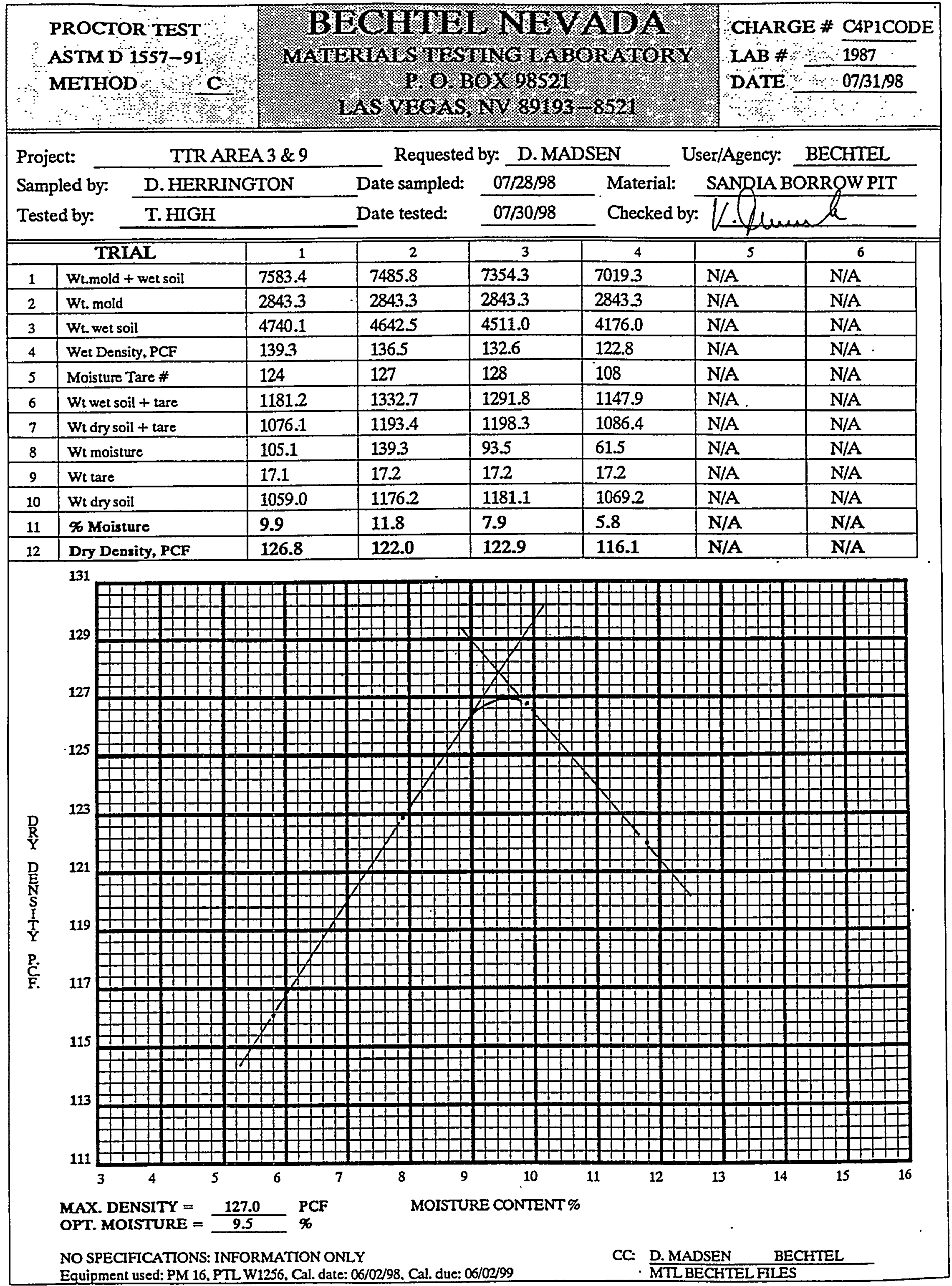




\begin{tabular}{|c|c|c|c|c|c|c|}
\hline 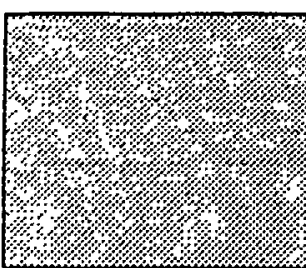 & 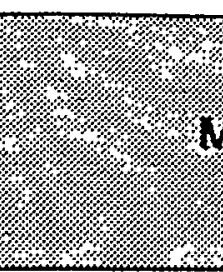 & WATERA & 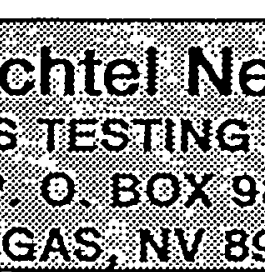 & 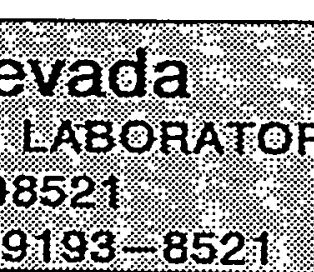 & 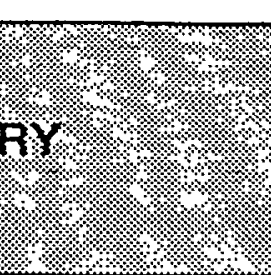 & 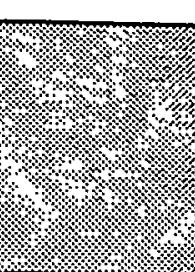 \\
\hline $\begin{array}{l}\text { Request } \\
\text { Requested by } \\
\text { UserlAgency }\end{array}$ & $\begin{array}{l}\text { est Repoit } \\
\text { D*MADSEN } \\
\text { BECHTEL }\end{array}$ & कै। & נै। & $\begin{array}{l}\text { कै } \\
\text { CCharge } \# \\
\text { MMTLLab \# }\end{array}$ & C4T2CODE & and \\
\hline Project: . & ITR AREA 9 & & & Material: & NATIVE & $\mathrm{A} 9 / 1$ \\
\hline Sampled by: & D. HERRINGT & TON & & Date Sampled: & $07 / 15 / 98$ & \\
\hline Teśted By: & T. HIGH \& D. & JOHNSON & & Date tested: & $07 / 20 / 98$ & \\
\hline Checked by: & D. HERRINGT & TON QAlX & & Date checked: & $9-2-98$ & \\
\hline LABORATORY TES & TREQUIRED & & & SIEVE ANALYSIS & $3\left(-3 / 8^{2}\right)$ & \\
\hline $\begin{array}{l}\text { Siove Analysis } \\
\text { (ASTM C-138-96) }\end{array}$ & & $\begin{array}{l}\text { U.S. Standard } \\
\text { Sieve \# }\end{array}$ & $\begin{array}{c}\text { Cumulative } \\
\text { Wt Retained }\end{array}$ & \% Retained & $\%$ Passing & $\begin{array}{l}\text { Spec \% } \\
\text { Passing }\end{array}$ \\
\hline \begin{tabular}{|l} 
(ASTM C-117-95) \\
$X$ \\
\end{tabular} & & $3^{n}$ & 0.0 & $0 \%$ & $100 \%$ & N/A \\
\hline $\begin{array}{l}\mathrm{X} \text { (ASTM D-1140-92) } \\
\text { Moisture Content }\end{array}$ & & $11 / 2^{\prime \prime}$ & 0.0 & $0 \%$ & $100 \%$ & N/A \\
\hline \begin{tabular}{|l|l} 
& (ASTM C-588-D8) \\
$\times$ & (ASTM D-2210-92) \\
\end{tabular} & & $3 / 4^{n}$ & 0.0 & $0 \%$ & $100 \%$ & N/A \\
\hline Unit Woight & & $3 / 8^{n}$ & 0.0 & $0 \%$ & $100 \%$ & N/A \\
\hline ] (ASTM C-20-91) & & 4 & 0.2 & $0 \%$ & $100 \%$ & N/A \\
\hline $\begin{array}{l}\text { Soil Classification } \\
\text { Porcent Porosity }\end{array}$ & & 10 & 8.2 & $1 \%$ & $99 \%$ & N/A \\
\hline Specific Gravity & . & 40 & 538.0 & $34 \%$ & $66 \%$ & $\bar{N} / \mathrm{A}$ \\
\hline $\begin{array}{l}\text { (ASTM C-127-88/128 } \\
\text { (ASTM D-584-92) }\end{array}$ & & 100 & 1165.1 & $73 \%$ & $27 \%$ & N/A \\
\hline I Other (as noted) & & $\cdot 200$ & 1394.1. & $87.3 \%$ & $12.7 \%$ & N/A \\
\hline Soil Class: & & Sample Wt (g): & $\mathrm{DAY}=$ & 1597.1 & WET $=$ & N/A \\
\hline - & & DISTURE CONT & [ENT & & UNIT WE & EIGHT \\
\hline & PAN \# 26 & N/A & N/A & & Loose & Rodded \\
\hline Wet Weight + Tare & 2512.5 & N/A & $N / A^{\circ}$ & Container Size( $\left(t^{\wedge} 3\right)$ & $N / A$ & N/A \\
\hline Dry Woight + Tare & 2500.2 & N/A & N/A & Total Weight (lb) & N/A & N/A \\
\hline Water & 12.3 & N/A & N/A & Tare Weight (lb) & N/A & N/A \\
\hline Tare & 903.1 & N/A & N/A & Material Weight (lb) & N/A & N/A \\
\hline Dry Weight & 1597.1 & N/A & N/A & Unit Weight (P.C.F.) & N/A & N/A \\
\hline Moisture \% & $0.8 \%$ & N/A & N/A & Percent Porosity & N/A & N/A \\
\hline Oversize Specific & Gravity: . & N/A & & Specific Gravity: & N/A & \\
\hline EQUIPMENT USED: & $M$ 16, PTL \#1256, & 6. Calibration Date: & $06 / 02 / 98$ & Calibration Due: $06 / 02 / 5$ & & \\
\hline Sieve $11 / 2^{n}$ & PTL \# Y303222 & Cal. Date: 03/27/98 & Cal. Due: 03/27/99 & REMARKS: & NONE & \\
\hline Sieve $3 / 4^{n}$ & PTL\# Y303276 & Cal. Date: 03/27/98 & Cal. Due: 03/27/99 & & & \\
\hline Sieve 3/8 & PTL\# Y302106 & Cal. Date: 03/27/98 & Cal. Due: 03/27/99 & & & \\
\hline Siove \# 4 & PTL \# Y302043 & Cel. Date: 03/26/98 & Cal. Due: 03/26/99 & & & \\
\hline Sieve \# 10 & PTL \# Y11621 & Cal. Date: 10/08/97 & Cal. Due: 10/08/99 & & & \\
\hline Siovo \# 16 & PTL\# Y302079 & Cal. Date: 03/25/98 & Cal. Due: 03/26/99 & & & \\
\hline Sieve \# 40 & PTL \# Y106 & Cal. Date: $10 / 09 / 97$ & Cal. Due: 10/09/99 & & & \\
\hline Slove \# 100 & PTL\# Y10035 & Cal. Date: 05/21/98 & Cal. Due: 05/21/99 & & & \\
\hline Siove \# 200 & PTL\#Y11599 & Cal. Date: 10/09/97 & Cal. Due: 10/09/99 & & & \\
\hline
\end{tabular}




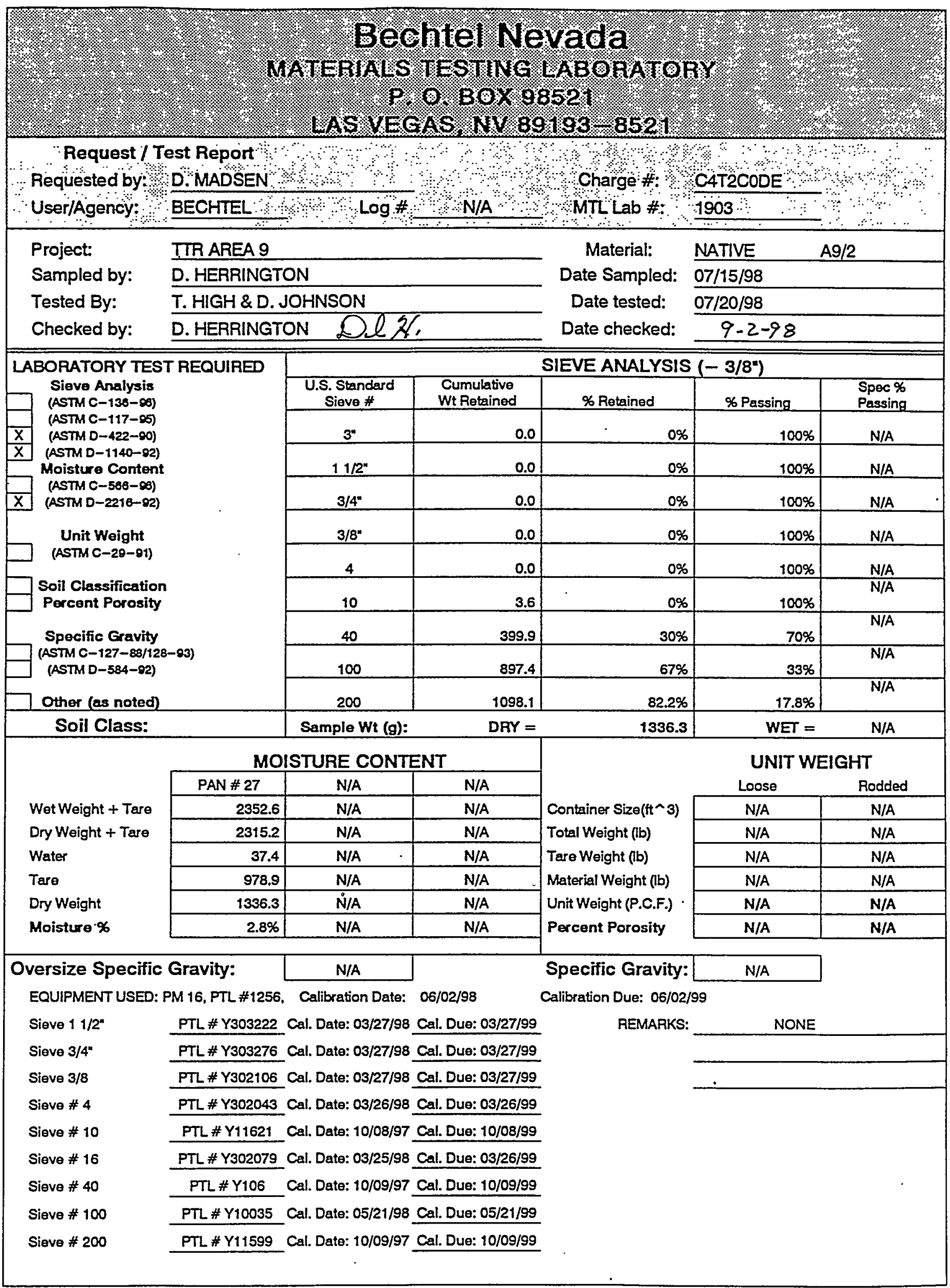




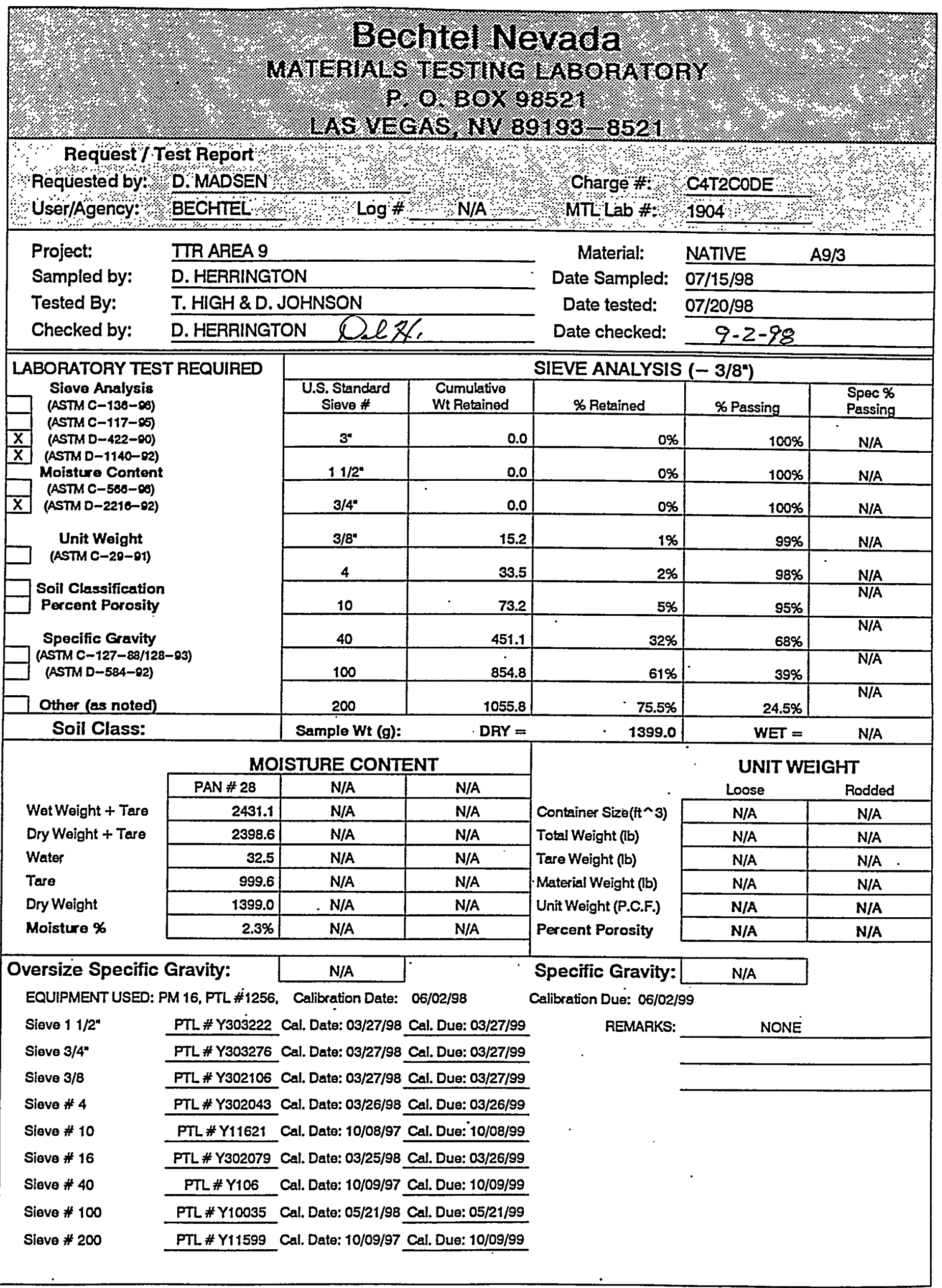




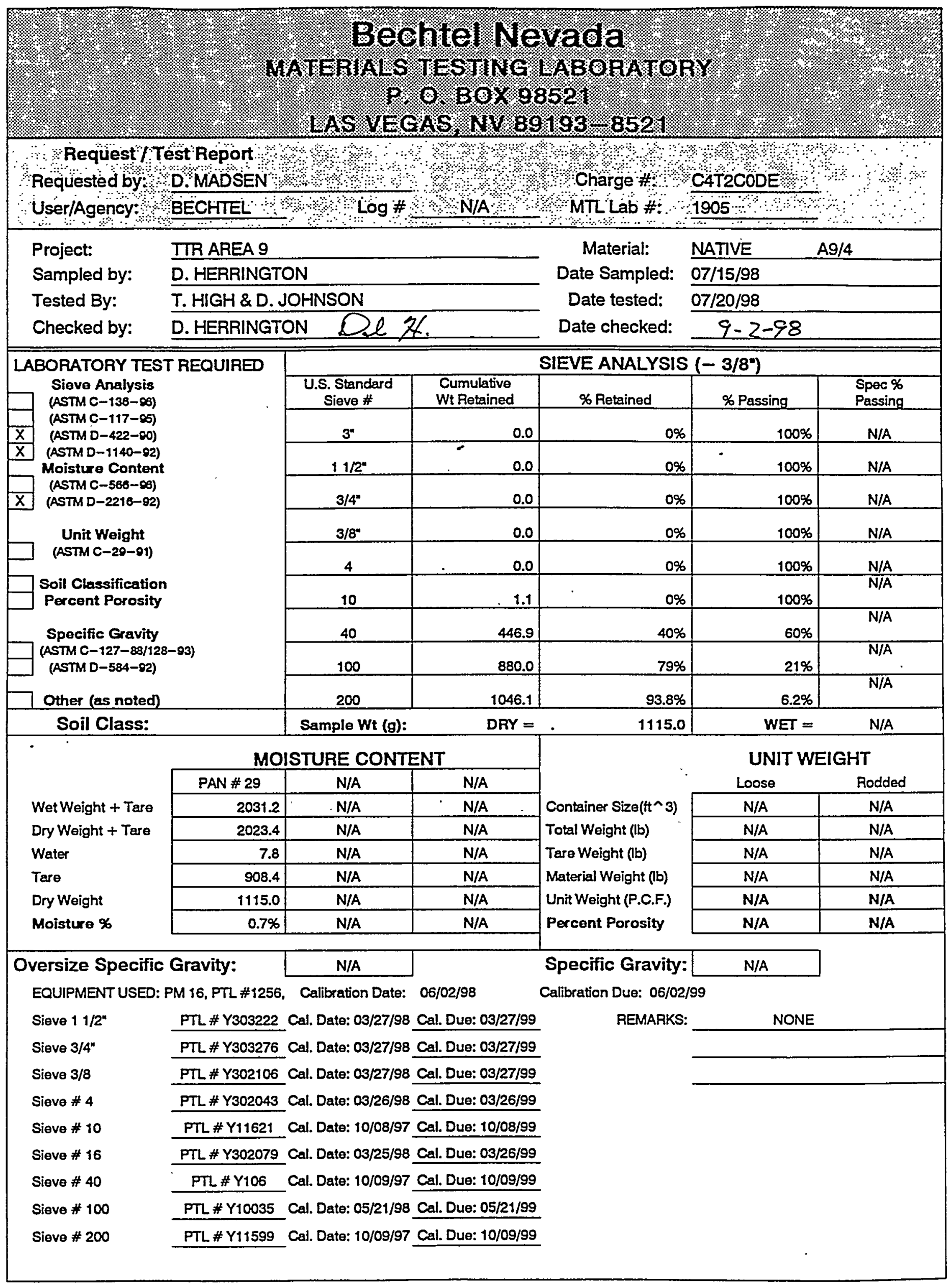




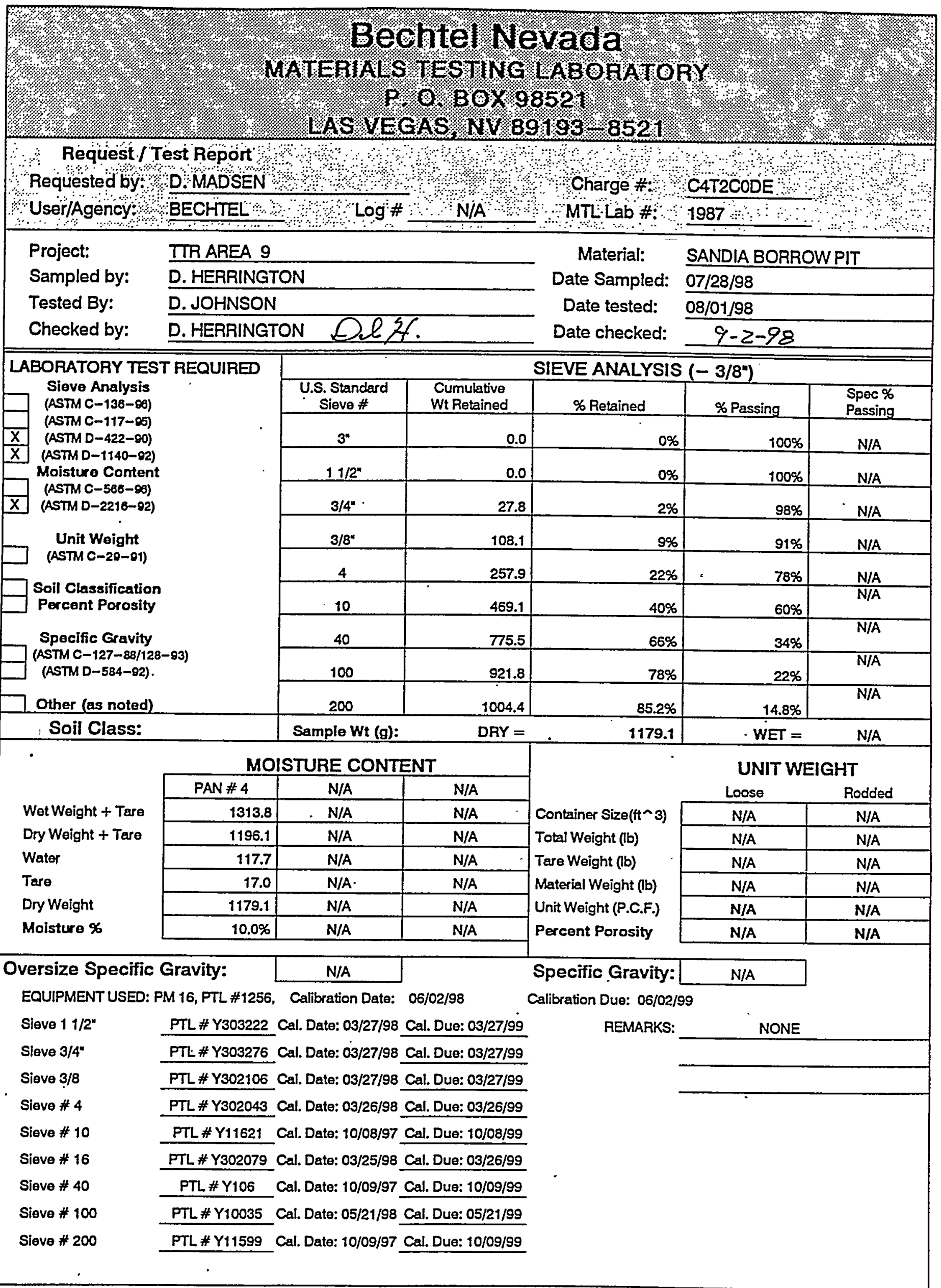




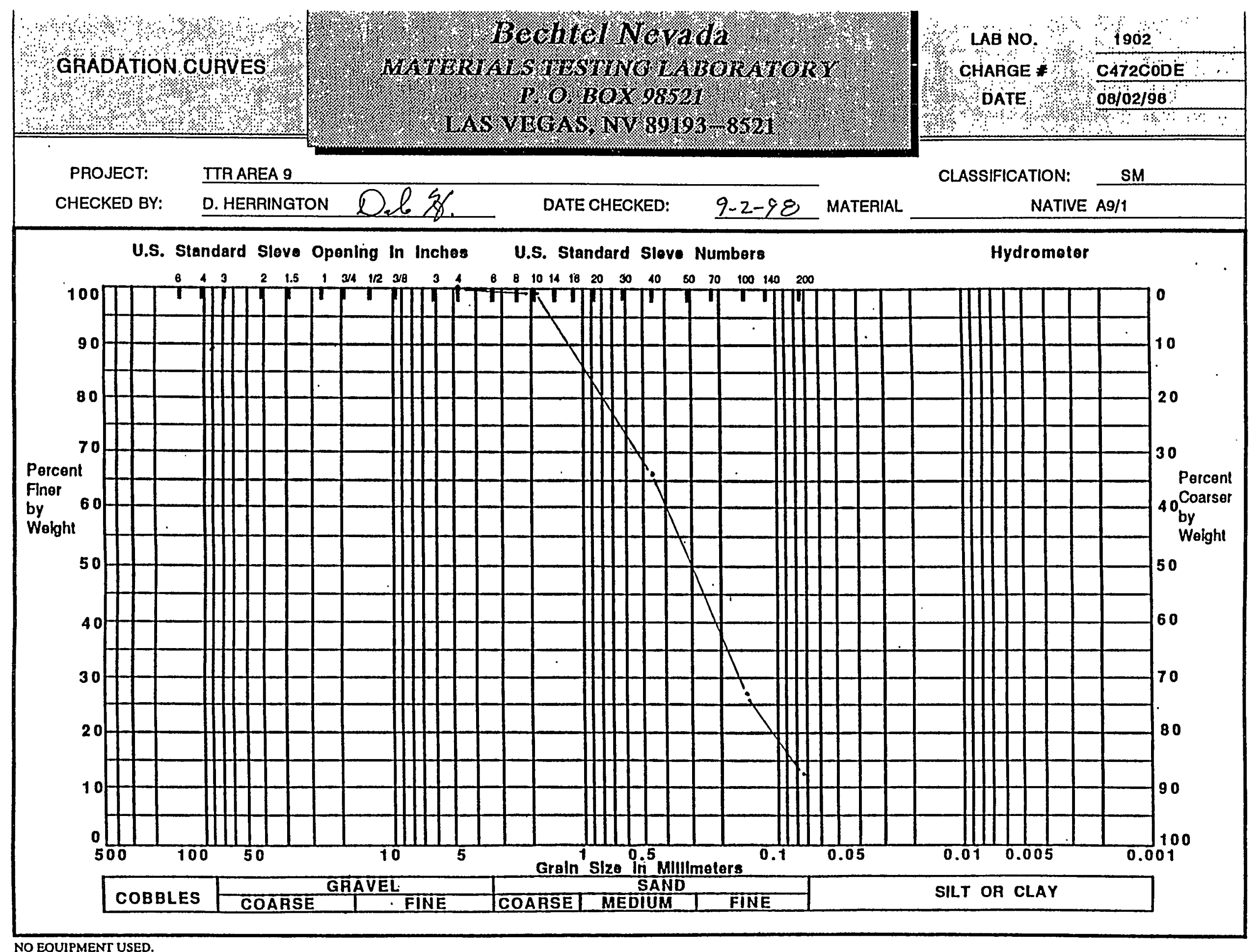




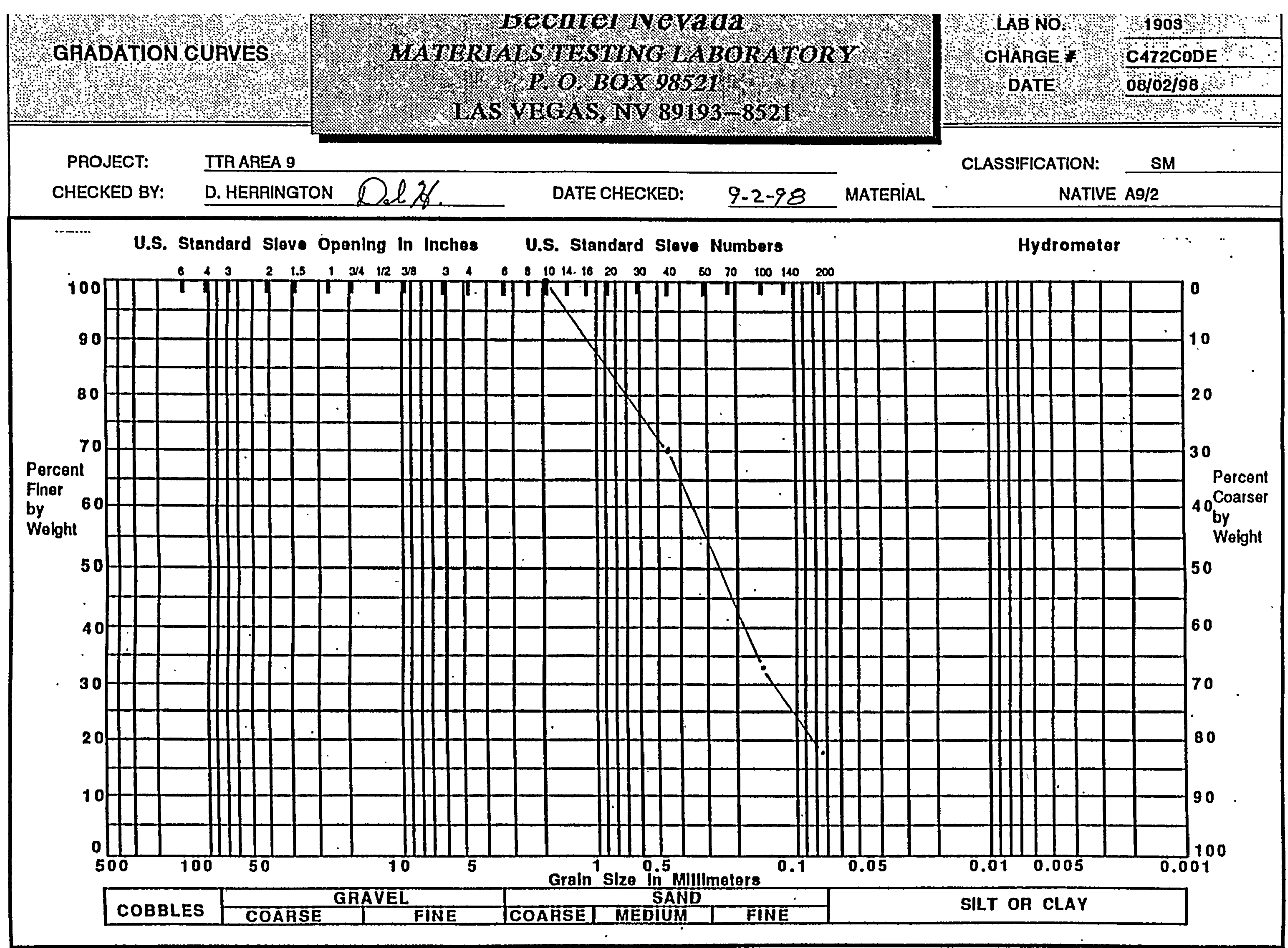

NO EQUIPMENT USED. 


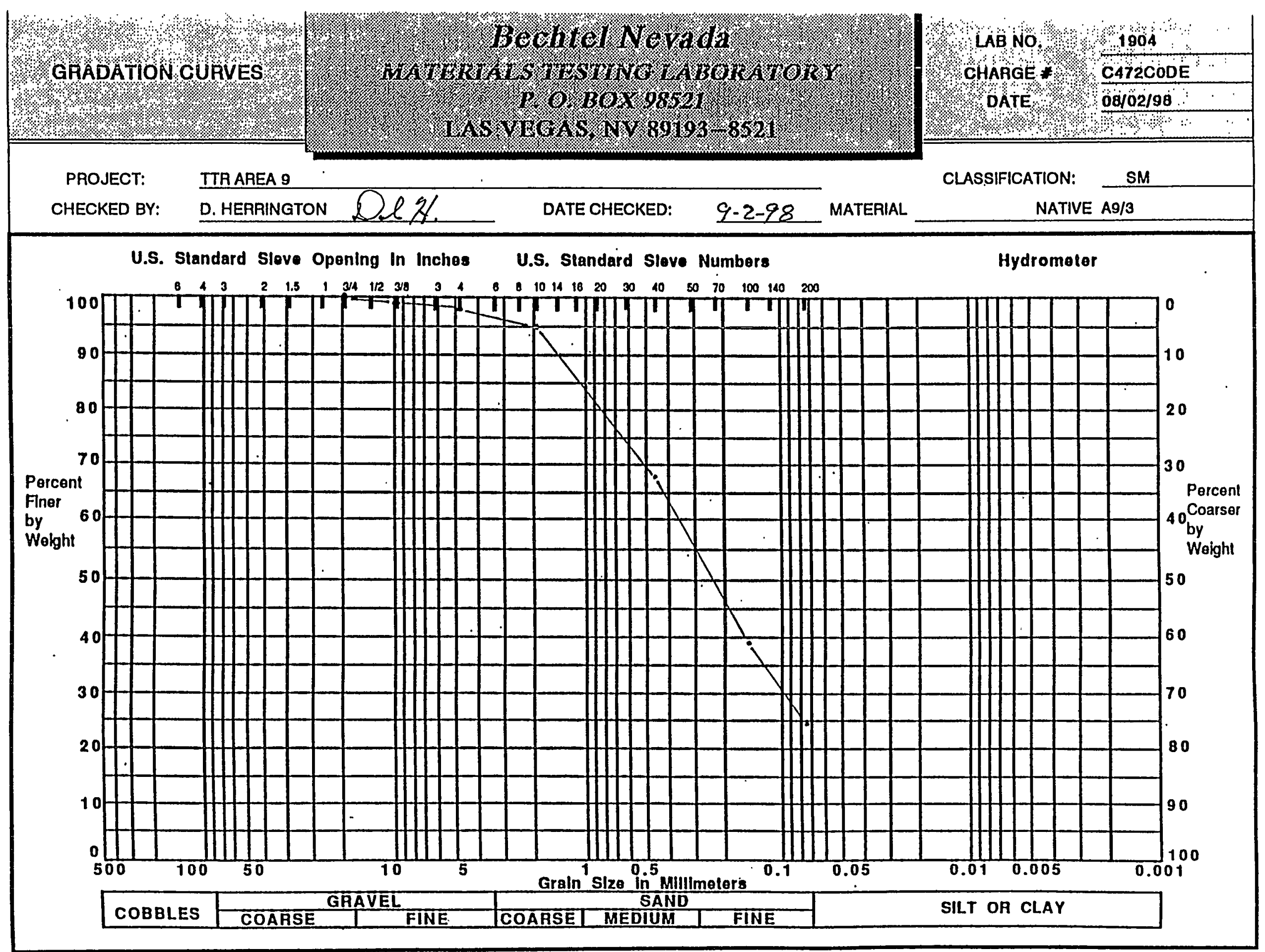




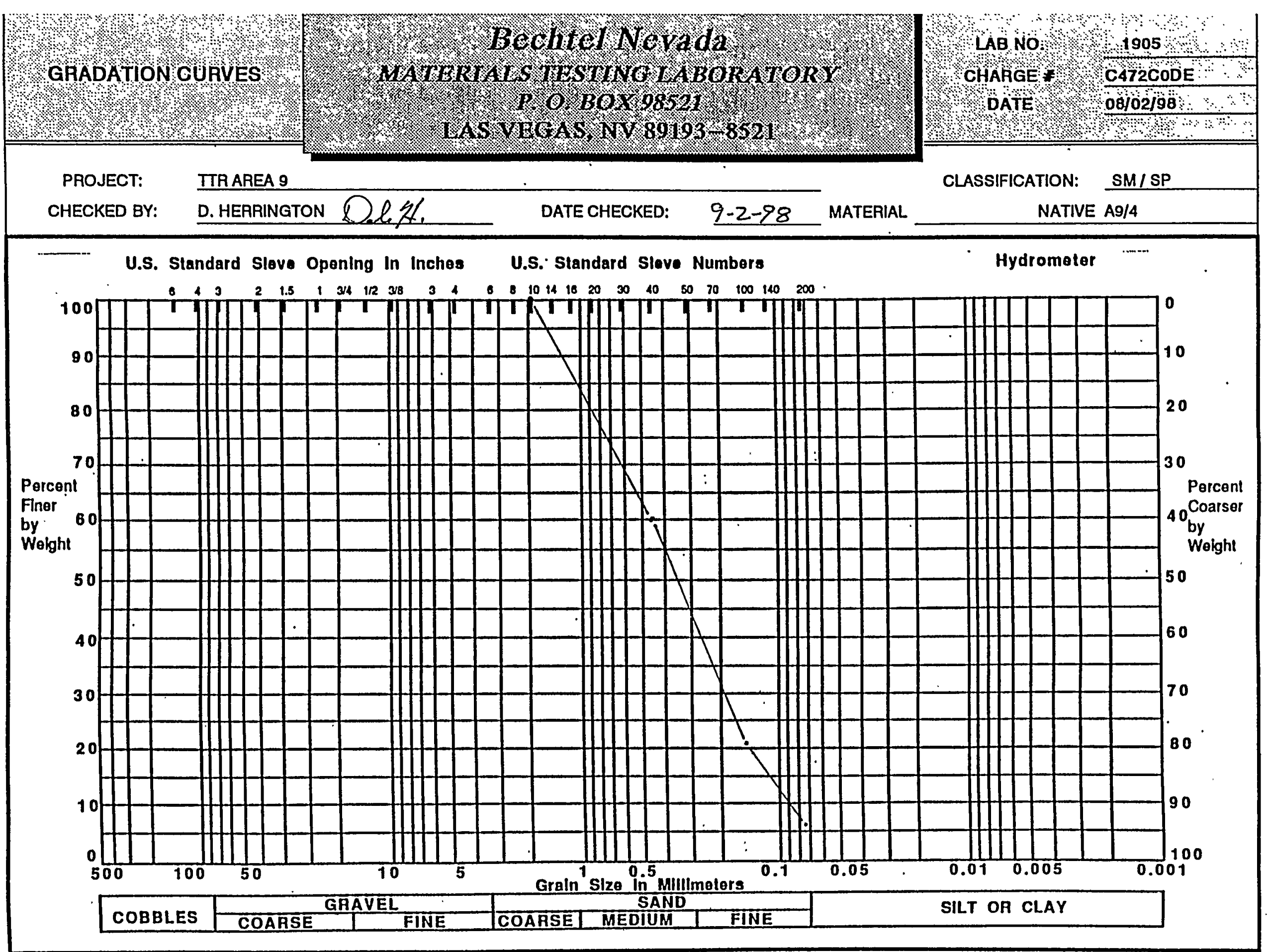




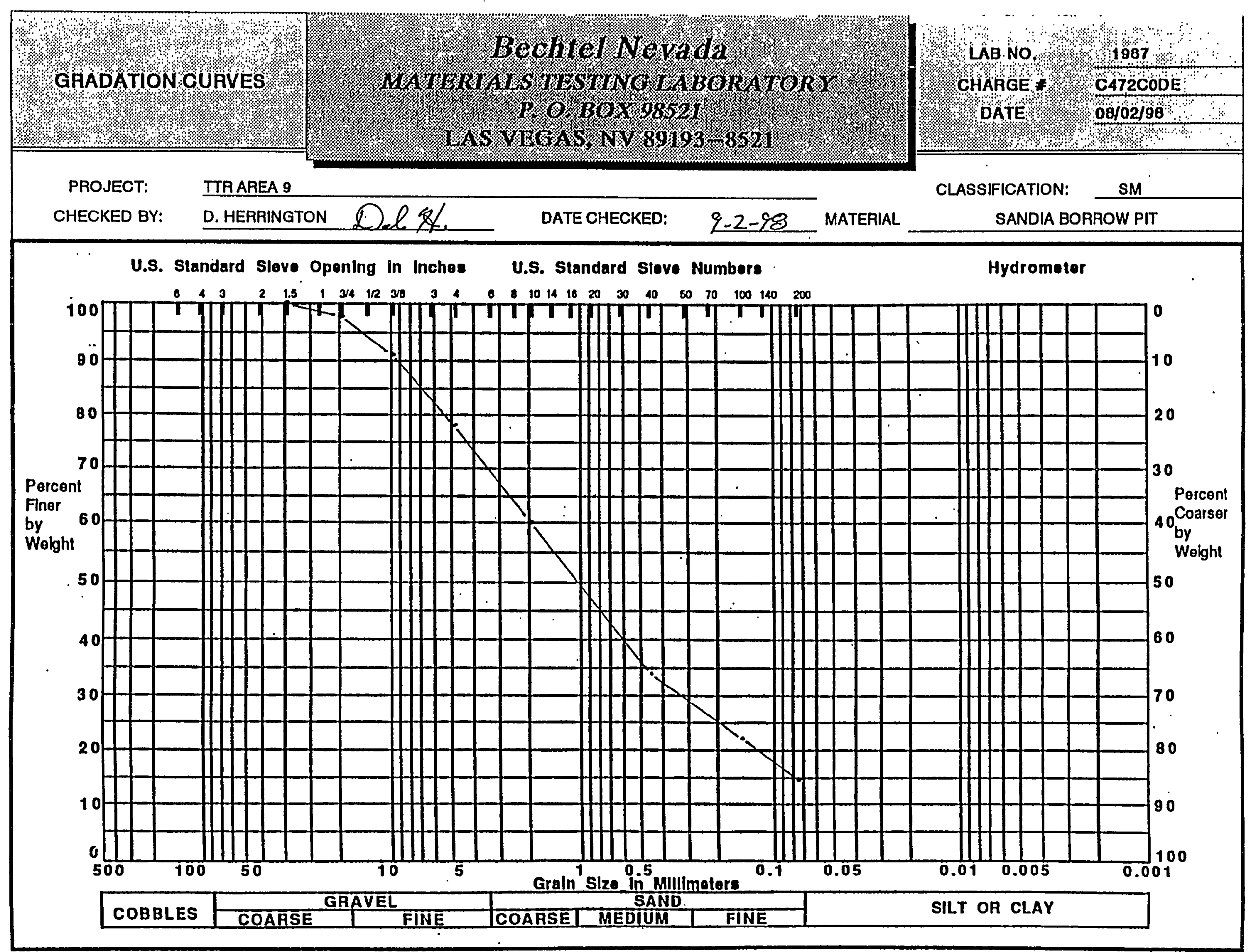




\section{Bechtel Nevada}

\section{Materials Testing Laboratory}

P.O.BOX 98521, M/S NTS 188, LAS VEGAS, NV 89193

(702) 295-6669

\section{Table 1.}

SAMPLE TTR PERMEABILITY TO DI WATER

ASTM D 2434-68 (Reapproved 1974)

Standard Test Method for Permeability of Granular Soils (Constant Head)

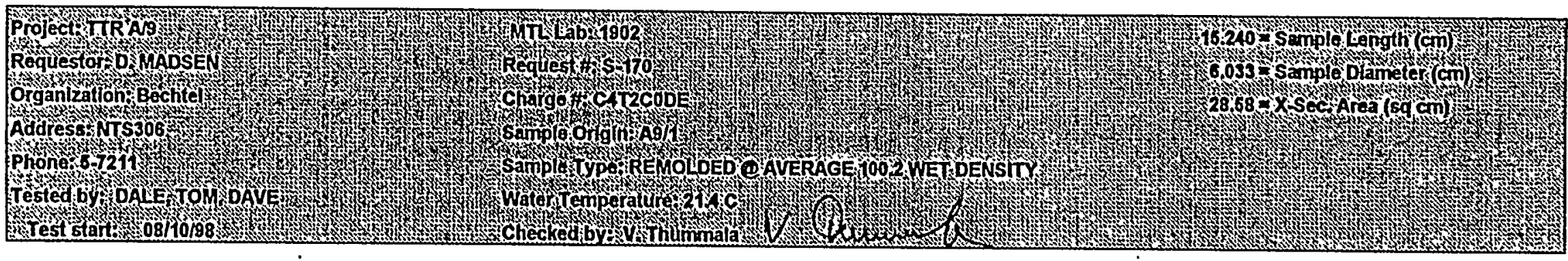

\begin{tabular}{|c|c|c|c|c|c|c|c|c|c|c|}
\hline $\begin{array}{l}\text { Reading } \\
\text { \#pays } \\
\text { Erom Start }\end{array}$ & $\begin{array}{l}\text { Manome } \\
\text { H1inim }\end{array}$ & 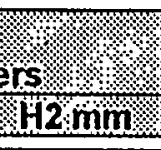 & $\begin{array}{l}\text { Head } \\
. \mathrm{cm}\end{array}$ & $\frac{\cos 3}{3}$ & (4. & 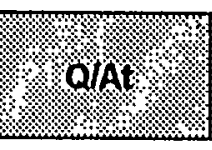 & (iill & $\begin{array}{l}1,20 \% \\
\mathrm{~cm} / \mathrm{sec}\end{array}$ & Date & Trime \\
\hline 7 & 954 & 55 & 89.9 & 10.00 & 372.0 & 0.0009 & 5.8990 & $E-04$ & $08 / 17$ & $\overline{A M}$ \\
\hline 7 & 953 & 55 & 89.8 & 10.00 & 360.0 & 097188 & 5.8924 & $1.60 \mathrm{E}-04$ & 08 & $A M$ \\
\hline 7 & 953 & 57 & 89.6 & 10.00 & 358.0 & 0.00097731 & 5.8793 & $1.61 \mathrm{E}-04$ & $08 / 17 / 98$ & AM \\
\hline 7 & 953 & 57 & 89.6 & 10.00 & 363.0 & 0.00096385 & 5.8793 & $1.59 \mathrm{E}-04$ & $08 / 17 / 98$ & AM \\
\hline
\end{tabular}

EQUIPMENT USED: METTLER PM400, PTL \# Y1255, Calibration Date: 05/21/98, Calibration Due: 05/21/99 


\section{Bechtel Nevada}

\section{Materials Testing Laboratory}

P.O.BOX 98521, M/S NTS 188, LAS VEGAS, NV 89193

(702) $295-6669$

\section{Table 2.}

SAMPLE TTR PERMEABILITY TO DI WATER

\section{ASTM D 2434-68 (Reapproved 1974)}

Standard Test Method for Permeability of Granular Soils (Constant Head)

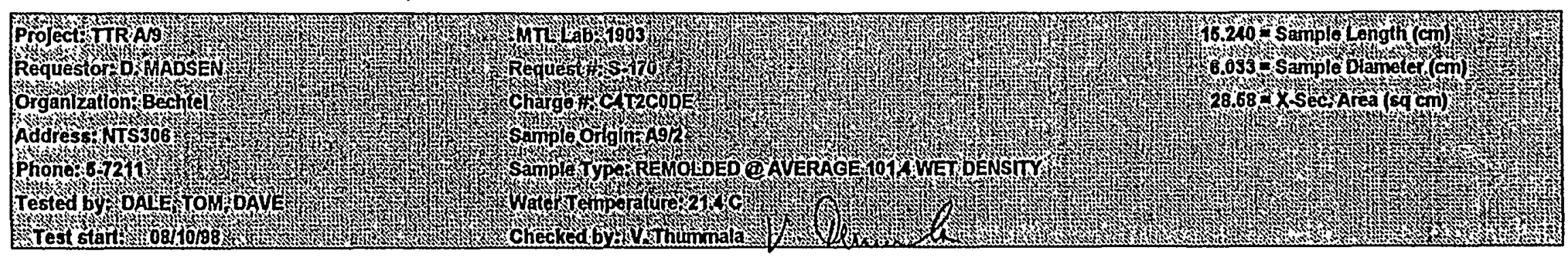

\begin{tabular}{|c|c|c|c|c|c|c|c|c|c|c|}
\hline $\begin{array}{l}\text { Reading } \\
\text { Foays } \\
\text { From Start }\end{array}$ & $\begin{array}{l}\text { Manome } \\
\text { Hinmmin }\end{array}$ & $\frac{\mathrm{ers}}{\mathrm{H} 2 \mathrm{~mm}}$ & Head. & 1.9. & sectivi. & QAA?: & hill. & $\begin{array}{l}4.20 \% \\
\text { cmisec }\end{array}$ & i & $\begin{array}{l}\text { Trime } \\
\text { Tested }\end{array}$ \\
\hline 7 & 955 & 64 & 89.1 & 10.00 & 454.0 & 0.00077065 & 5.8465 & $1.28 \mathrm{E}-04$ & $08 / 17 / 98$ & AM \\
\hline 7 & 955 & 60 & 89.5 & 10.00 & 396.0 & 0.00088353 & 5.8727 & $1.46 \mathrm{E}-04$ & $08 / 17 / 98$ & AM \\
\hline 7 & 955 & 60 & 89.5 & 10.00 & 389.0 & 0.00089943 & 5.8727 & $1.49 \mathrm{E}-04$ & $08 / 17 / 98$ & $\overline{A M}$ \\
\hline 7 & 955 & 59 & 89.6 & 10.00 & 377.0 & 0.00092806 & 5.8793 & $1.53 E-04$ & $08 / 17 / 98$ & AM \\
\hline 7 & 955 & 59 & 89.6 & 10.00 & 367.0 & 0.00095334 & 5.8793 & 1.57E-04 & $08 / 17 / 98$ & $\overline{A M}$ \\
\hline & & & & & & & & & & \\
\hline EQUIPMENT & USED: & METTLER & $400, \mathrm{PTL}$ & \#Y1255, Calip & tion Date: 05 & 121/98, Calibra & ation Due: 05 & $1 / 99$ & & \\
\hline
\end{tabular}




\section{Bechtel Nevada}

\section{Materials Testing Laboratory}

P.O.BOX 98521, M/S NTS 188, LAS VEGAS, NV 89193

(702) 295-6669

\section{Table 3}

SAMPLE TTR PERMEABILITY TO DI WATER

ASTM D 2434-68 (Reapproved 1974)

Standard Test Method for Permeability of Granular Soils (Constant Head)

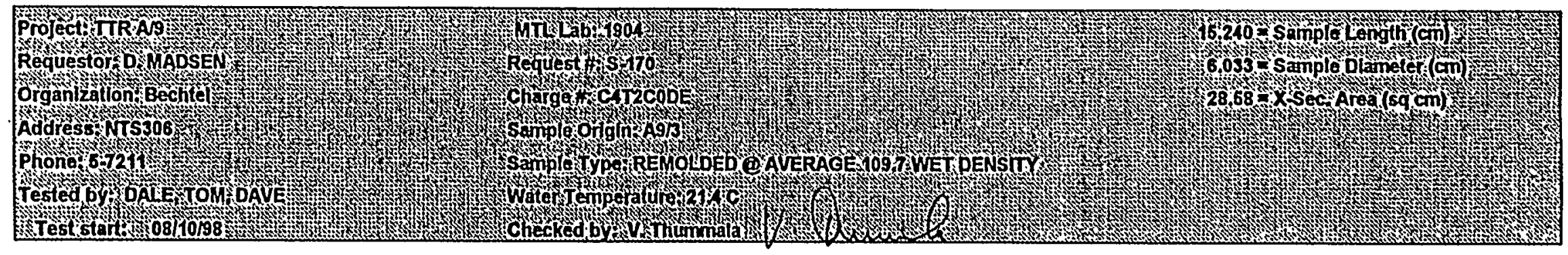

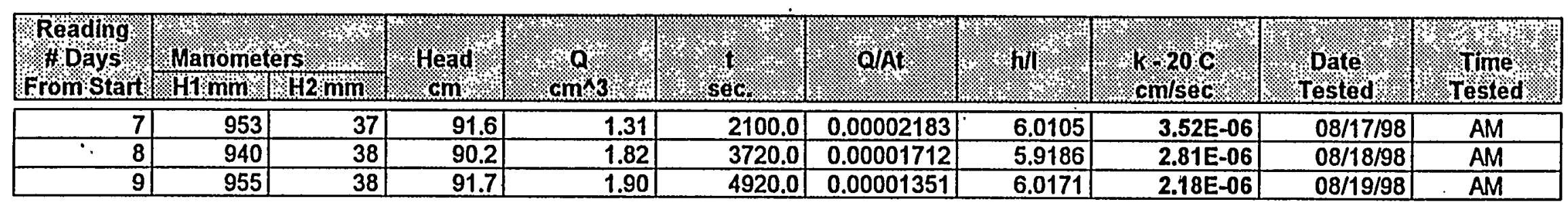

EQUIPMENT USED: METTLER PM400, PTL \# Y1255, Calibration Date: 05/21/98, Calibration Due: 05/21/99 


\section{Bechtel Nevada}

\section{Materials Testing Laboratory}

P.O.BOX 98521, M/S NTS 188, LAS VEGAS, NV 89193

(702) 295-6669

\section{Table 4}

SAMPLE TTR PERMEABILITY TO DI WATER

ASTM D 2434-68 (Reapproved 1974)

Standard Test Method for Permeability of Granular Soils (Constant Head)

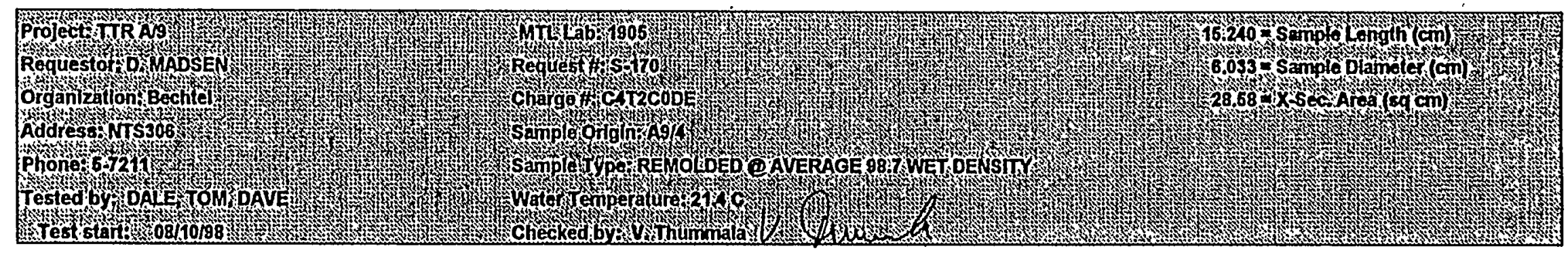

\begin{tabular}{|c|c|c|c|c|c|c|c|c|c|c|}
\hline $\begin{array}{l}\text { Reading } \\
\text { \#pays } \\
\text { Erom Start }\end{array}$ & $\begin{array}{l}\text { Manomet } \\
\text { H1.mm }\end{array}$ & $\frac{\mathrm{ers}}{\mathrm{H} 2 \mathrm{~mm}}$ & 1.eara & $\frac{9}{\operatorname{com} \times 3}$ & 1.: & (1) QIA? & ili & . & Tate & 18 Time \\
\hline 2 & 925 & 37 & 88.8 & 10.00 & 12.0 & 0.02915642 & \begin{tabular}{|l|}
5.8268 \\
\end{tabular} & $4.86 \mathrm{E}-03$ & $08 / 12 / 98$ & $A M$ \\
\hline 2 & 925 & 37 & 88.8 & 10.00 & 12.0 & 0.02915642 & 5.8268 & 4.86E-03 & $08 / 12 / 98$ & AM \\
\hline 2 & 925 & 37 & 88.8 & 10.00 & 12.0 & 0.02915642 & 5.8268 & 4.86E-03 & $08 / 12 / 98$ & $A M$ \\
\hline 2 & 925 & 37 & 88.8 & 10.00 & 12.0 & 0.02915642 & 5.8268 & $4.86 \mathrm{E}-03$ & $08 / 12 / 98$ & AM \\
\hline 2 & 963 & 52 & 91.1 & 10.00 & 11.0 & 0.03180700 & 5.9777 & $5.16 \mathrm{E}-03$ & $08 / 12 / 98$ & AM \\
\hline 2 & 963 & 52 & 91.1 & 10.00 & 11.0 & 0.03180700 & 5.9777 & $5.16 \mathrm{E}-03$ & $08 / 12 / 98$ & $A M$ \\
\hline EQUIPMENT & USED: & METTLER & M400, PTL & \#Y1255, Calik & ration Date: 0 & /21/98, Calibr & ation Due: 05 & $21 / 99$ & & \\
\hline
\end{tabular}




\section{Bechtel Nevada}

\section{Materials Testing Laboratory}

P.O.BOX 98521, M/S NTS 188, LAS VEGAS, NV 89193

(702) 295-6669

\section{Table 8.}

SAMPLE TTR PERMEABILITY TO DI WATER

\section{ASTM D 2434-68 (Reapproved 1974)}

Standard Test Method for Permeability of Granular Soils (Constant Head)

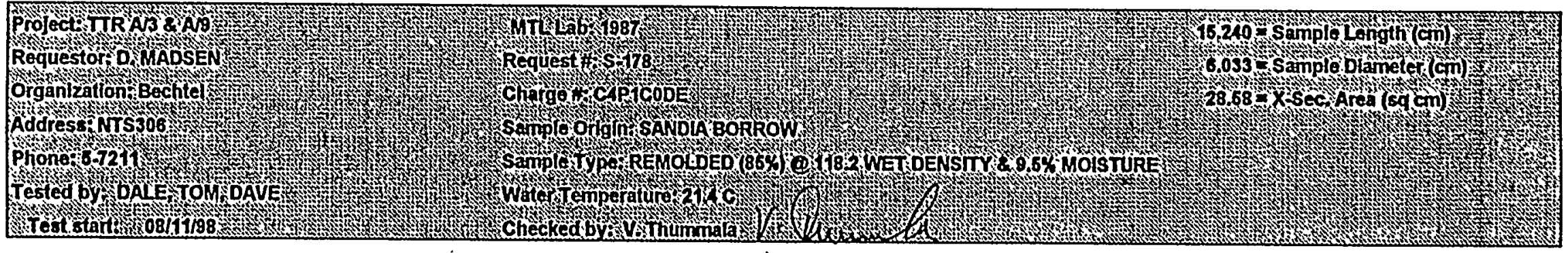

\begin{tabular}{|c|c|c|c|c|c|c|c|c|c|c|}
\hline $\begin{array}{l}\text { Reading } \\
\text { Hoays } \\
\text { Fromstart }\end{array}$ & $\begin{array}{l}\text { Manomet } \\
\text { Htmmi } \\
\text { Himis }\end{array}$ & $\frac{15}{1 \mathrm{H} 2 \mathrm{~mm}}$ & $\begin{array}{l}\text { \% } \\
\text { \%ead } \\
\text { chin }\end{array}$ & 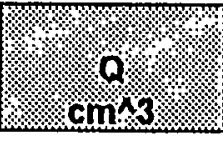 & \%. & $8 \%$ Qtat & +2. & 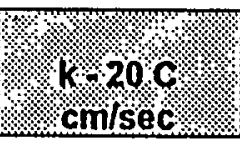 & 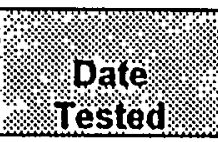 & $\begin{array}{l}2 \\
\text { Trimes } \\
\text { Tosted }\end{array}$ \\
\hline 8 & 958 & 49 & 90.9 & 10.00 & 80.0 & 0.00437346 & 5.9646 & 7.11E-04 & $08 / 18 / 98$ & $\overline{A M}$ \\
\hline 8 & 958 & 42 & 91.6 & 10.00 & 87.0 & 0.00402158 & 6.0105 & $6.49 \mathrm{E}-04$ & $08 / 18 / 98$ & AM \\
\hline 8 & 958 & 39 & 91.9 & 10.00 & 68.0 & 0.00514525 & 6.0302 & $8.28 E-04$ & $08 / 18 / 98$ & $\overline{A M}$ \\
\hline 8 & 958 & 39 & 91.9 & 10.00 & 61.0 & 0.00573569 & 6.0302 & 9.23E-04 & $08 / 18 / 98$ & $A M$ \\
\hline 8 & 958 & 40 & 91.8 & 10.00 & 63.0 & 0.00555360 & 6.0236 & 8.95E-04 & $08 / 18 / 98$ & $\mathrm{AM}$ \\
\hline
\end{tabular}

EQUIPMENT USED: METTLER PM400, PTL \# Y1255, Calibration Date: 05/21/98, Calibration Due: 05/21/99 


\section{Bechtel Nevada}

\section{Materials Testing Laboratory}

P.O.BOX 98521, M/S NTS 188, LAS VEGAS, NV 89193

(702) 295-6669

\section{Table 9.}

SAMPLE TTR PERMEABILITY TO DI WATER

ASTM D 2434-68 (Reapproved 1974)

Standard Test:Method for Permeability of Granular Soils (Constant Head)

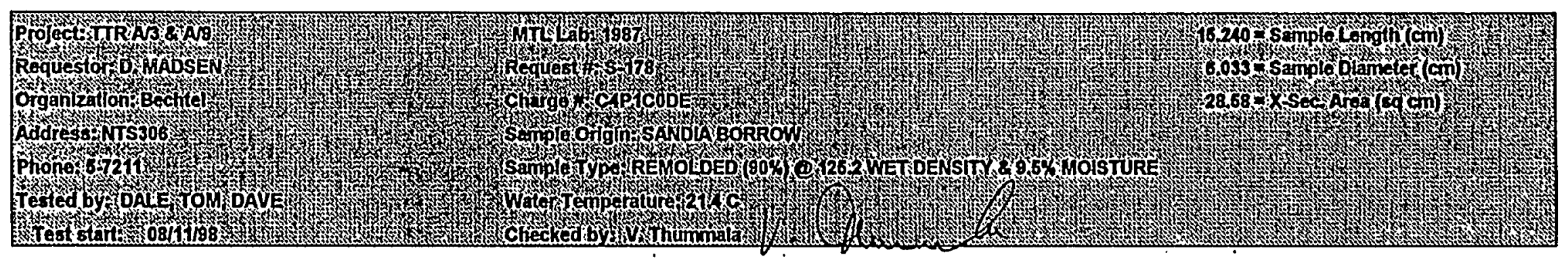

\begin{tabular}{|c|c|c|c|c|c|c|c|c|c|c|}
\hline $\begin{array}{l}\text { Reading } \\
\text { H pays }\end{array}$ & Manome & & Head & 19. & 1/ & Q/A. & fill: & 91.20 & pate & Time \\
\hline Fromstart & Hi1 $\mathrm{mm}$ & $\mathrm{HLmm}$ & $=$. & $\operatorname{cm} \times 3$ & $85 e c$ & & & amisec & Tested & Tested \\
\hline 8 & 957 & 38 & 91.9 & 0.30 & 107.0 & 0.00009810 & 6.0302 & $1.58 E-05$ & $08 / 18 / 98$ & $\overline{A M}$ \\
\hline 8 & 957 & 38 & 91.9 & 0.73 & 100.0 & 0.00025541 & 6.0302 & $4.11 E-05$ & $08 / 18 / 98$ & $A M$ \\
\hline 8 & 957 & 40 & 91.7 & 0.65 & 105.0 & 0.00021659 & 6.0171 & $3.49 E-05$ & $08 / 18 / 98$ & $\overline{A M}$ \\
\hline 8 & 957 & 40 & 91.7 & 0.90 & 127.0 & 0.00024794 & 6.0171 & $4.00 \mathrm{E}-05$ & $08 / 18 / 98$ & $A M$ \\
\hline 8 & 957 & 42 & 91.5 & 0.85 & 128.0 & 0.00023234 & 6.0039 & $3.75 E-05$ & $08 / 18 / 98$ & AM \\
\hline 8 & 957 & 40 & 91.7 & 0.78 & 121.0 & 0.00022554 & 6.0171 & $3.64 E-05$ & $08 / 18 / 98$ & $\overline{A M}$ \\
\hline
\end{tabular}

EQUIPMENT USED: METTLER PM400, PTL \# Y1255, Calibration Date: 05/21/98, Calibration Due: 05/21/99 


\section{Bechtel Nevada}

\section{Materials Testing Laboratory}

P.O.BOX 98521, M/S NTS 188, LAS VEGAS, NV 89193

(702) 295-6669

\section{Table 10.}

SAMPLE TTR PERMEABILITY TO DI WATER

ASTM D 2434-68 (Reapproved 1974)

Standard Test Method for Permeability of Granular Soils (Constant Head)

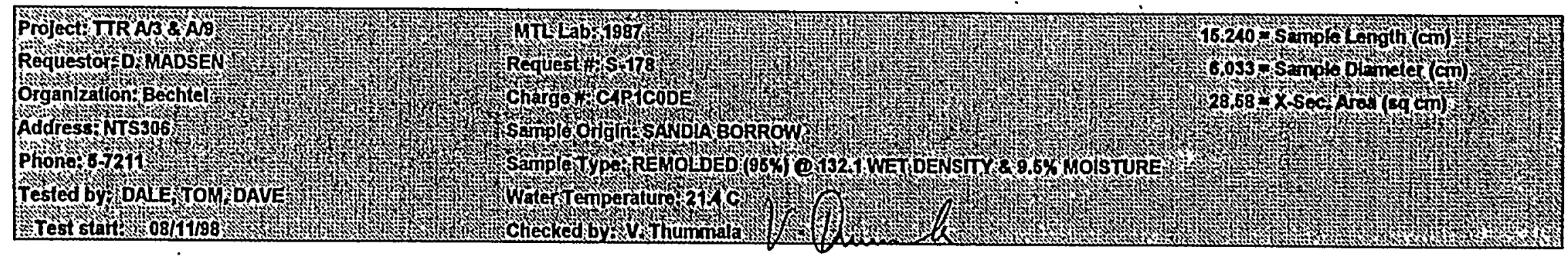

\begin{tabular}{|c|c|c|c|c|c|c|c|c|c|c|}
\hline $\begin{array}{l}\text { Reading } \\
\text { Hoays } \\
\text { rom start }\end{array}$ & $\begin{array}{l}\text { Manomet } \\
\text { H1mmin }\end{array}$ & $\begin{array}{l}\mathrm{rs} \\
\mathrm{H} 2 \mathrm{~mm}\end{array}$ & \%head & $8.8 \cos ^{3}$ & \$.t. & $1 \%$ alat & $1 \%$ & 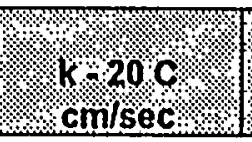 & \%topte & $\begin{array}{l}\text { mtime } \\
\text { me sted }\end{array}$ \\
\hline 8 & 957 & 36 & 92.1 & 0.72 & 370.0 & 0.00006808 & 6.0433 & $1.09 \mathrm{E}-05$ & $08 / 18 / 98$ & $\mathrm{AM}$ \\
\hline 8 & 957 & 40 & 91.7 & 0.40 & 68.0 & 0.00020581 & 6.0171 & $3.32 \mathrm{E}-05$ & $08 / 18 / 98$ & $A M$ \\
\hline 8 & 957 & 40 & 91.7 & 1.11 & 199.0 & 0.00019516 & 6.0171 & $3.15 \mathrm{E}-05$ & $08 / 18 / 98$ & $\mathrm{AM}$ \\
\hline 8 & 955 & 38 & 91.7 & 0.70 & 473.0 & 0.00005178 & 6.0171 & $8.35 E-06$ & $08 / 18 / 98$ & $\mathrm{AM}$ \\
\hline 8 & 955 & 36 & 91.9 & 0.95 & 678.0 & 0.00004902 & 6.0302 & 7.89E-06 & $08 / 18 / 98$ & $A M$ \\
\hline 8 & 955 & 40 & 91.5 & 0.70 & 373.0 & 0.00006566 & 6.0039 & $1.06 \mathrm{E}-05$ & $08 / 18 / 98$ & $A M$ \\
\hline 8 & 954 & 37 & 91.7 & 0.74 & 330.0 & 0.00007846 & 6.0171 & 1.27E-05 & $08 / 18 / 98$ & $A M$ \\
\hline 8 & 954 & 37 & 91.7 & 0.50 & 357.0 & 0.00004900 & 6.0171 & 7.90E-06 & $08 / 18 / 98$ & $\overline{A M}$ \\
\hline 8 & 953 & 38 & 91.5 & 0.67 & 484.0 & 0.00004843 & 6.0039 & $7.83 \mathrm{E}-06$ & $08 / 18 / 98$ & $\overline{A M}$ \\
\hline 8 & 953 & 38 & 91.5 & 0.48 & 196.0 & 0,00008568 & 6.0039 & $1.38 \mathrm{E}-05$ & $08 / 18 / 98$ & $\overline{A M}$ \\
\hline 8 & 953 & 38 & 91.5 & 0.63 & 243.0 & 0.00009071 & 6.0039 & 1.47E-05 & $08 / 18 / 98$ & $\mathrm{AM}$ \\
\hline 8 & 953 & 38 & 91.5 & 1.00 & 428.0 & 0.00008175 & 6.0039 & 1.32E-05 & $08 / 18 / 98$ & AM \\
\hline
\end{tabular}

EQUIPMENT USED: METTLER PM400, PTL\# Y1255, Calibration Date: 05/21/98, Calibration Due: 05/21/99 


\section{DISTRIBUTION LIST}




\section{DISTRIBUTION LIST}

Copies

Controlled

Bureau of Federal Facilities

Division of Environmental Protection

333 W. Nye Lane, room 13B

Carson City, NV 89706-0866

P. J. Liebendorfer

K. K. Beckley

U. S. Department of Energy, Nevada Operations Office

P. O. Box 98518

Las Vegas, NV 89193-8518

S. D. Lawrence

Copies

Uncontrolled Copies

U. S. Department of Energy, Nevada Operations Office

P. O. Box 98518

Las Vegas, NV 89193-8518

J. L. Appenzeller-Wing

K. J. Cabble

Public Reading Room

1

Technical Information Resource Center

U. S. Department of Energy,

Office of Scientific and Technical Information

175 Oak Ridge Turnpike

P. O. Box 62

Oak Ridge, TN 37831 


\section{DISTRIBUTION LIST (continued)}

\section{Copies}

\section{Bechtel Nevada}

P. O. Box $98521, \mathrm{M} / \mathrm{S}$ NLV008

Las Vegas, NV 89193-8521

Correspondence Control

D. K. Cowser

D. D. Madsen

S. J. Nacht

C. M. Obi

K. A. Quintana

IT Corporation

4330 South Valley View, Suite 114

Las Vegas, NV 89103-4047

K. C. Beach

M. E. Todd
Uncontrolled Copies 